\title{
Assessment of shear zone-derived quartz from the Etam area, southwest Cameroon as potential high-purity quartz resource: petrography, geochemistry and technological studies
}

\author{
Cyrille Sigue ${ }^{1,2} \cdot$ Amidou Moundi $^{3} \cdot$ Cheo Emmanuel Suh $^{1,5} \cdot$ Murilo Ferreira Marques dos Santos $^{4} \cdot$ Eric Fujiwara $^{4}$. \\ Carlos Kenichi Suzuki ${ }^{4}$ Jean Lavenir Ndema-Mbongue ${ }^{1,2}$
}

Received: 5 October 2019 / Accepted: 18 February 2020 / Published online: 4 March 2020

(c) Springer Nature Switzerland AG 2020

\begin{abstract}
This study focuses on the evaluation of the high-purity quartz (HPQ) potential of a shear zone-hosted hydrothermal and metamorphic quartz deposit in Etam, southwest Cameroon. The shear zone quartz-rich rock is monomineralic and consists of both milky and translucent varieties. The combination of ICP-MS and LA-ICP-MS analytical techniques was used to assess the chemical purity of both quartz varieties. These compositional analyses show that all quartz samples have $\mathrm{SiO}_{2}$ content of $98.46-99.75 \mathrm{wt} \%$ with very low concentrations of all the other elements. Translucent quartz when compared to the milky quartz variety shows low concentration of most of the elements including the following principal impurities: Al (mean $107 \mu \mathrm{g} \mathrm{g}^{-1}$ ), Ca (mean $27.85 \mu \mathrm{g} \mathrm{g}^{-1}$ ) and Fe (mean $26.05 \mu \mathrm{g} \mathrm{g}^{-1}$ ). Bubble generation in the samples after flame fusion over a silica plate was assessed to test the suitability of the quartz in industrial uses. The results obtained from the chemical analyses and bubble formation tests indicate that all the samples investigated do not meet the HPQ requirement. However, the translucent quartz shows characteristics of medium-purity quartz and can produce silica glass for some industrial manufacturing even without further purification. In this study, the fluid inclusions in the samples were examined as this bears information on the economic viability of the deposit and provides clues on the genesis of the quartz vein. Also tiny mineral inclusions within individual quartz grains were identified by SEM-EDS. The results of these studies show that the deposit is probably of metamorphic origin marked by crystal-plastic deformation in quartz grains. The veins were later modified by hydrothermal fluid input. The results also indicate that the majority of impurities are likely hosted by fluid inclusions and thus the quartz can be upgraded to HPQ after purification by suitable methods.
\end{abstract}

Keywords Hydrothermal · Metamorphic · Cameroon · Shear zone · Silica glass · High-purity quartz (HPQ)

\section{Introduction}

The high-purity quartz (HPQ) market is presently characterized by a stable growth and annually increases by 3 to $5 \%$. Despite this constant increase in the worldwide demand [1-3], quartz raw material resources with high purity are rare. An alternative solution to assure the HPQ supply for industries today can be the purification of medium- and low-purity quartz to upgrade the quartz grade. $\mathrm{HPQ}$ is an important raw material required for the production of silica glass $[4,5]$, and it is widely used in the electronics industry and advanced telecommunication and navigation devices.

Cyrille Sigue, siguecyrille@gmail.com | ${ }^{1}$ Economic Geology Unit, Department of Geology, University of Buea, P.O. Box 63, Buea, Cameroon. ${ }^{2}$ Laboratory of Geosciences for Internal Formations and Applications, Department of Earth Sciences, Faculty of Science, University of Yaoundé I, P.O. Box 3412, Yaoundé, Cameroon. ${ }^{3}$ Department of Earth Sciences, University of Yaoundé I, P.O. Box 3412, Yaoundé, Cameroon. ${ }^{4}$ Laboratory of Photonic Materials and Devices, School of Mechanical Engineering, University of Campinas (UNICAMP), R. Mendeleyev 200, Campinas 13083-860, Brazil. ${ }^{5}$ Department of Geology, Mining and Environmental Science, The University of Bamenda, P.O. Box 39, Bambili, North West Region, Cameroon. 
Muller et al. [6] determined that for quartz to be classified as $\mathrm{HPQ}$, the total impurity content should be less than $50 \mu \mathrm{g} \mathrm{g}^{-1}$. The high content of some impurities such as $\mathrm{Al}, \mathrm{Ti}, \mathrm{Ge}$ and Fe affects drastically the quality of quartz [7-11]. For example, Al content can generate devitrification, resulting in cristobalite white spots, whereas Ti and Fe can contaminate the silicon melt [11] derived from HPQ during industrial applications. Another type of impurity in quartz is fluid inclusions. Despite the fact that fluid inclusions are less difficult to remove in quartz compared to metallic impurities ( $\mathrm{Ti}, \mathrm{Fe}, \mathrm{Ge}$ ), they can also jeopardize the suitability of quartz as an industrial raw material. Some characteristics of silica glasses made from HPQ also depend on the chemical purity and the amount of fluid inclusions in the raw material. Examples are the transparency in UV and visible ranges, resistance to radiation and mechanical strength [10, 12].

Purification of low-purity quartz using industrial processing is often very costly, laborious and constitutes environmental hazard [1, 11, 13, 14]. Medium-purity quartz with good technological behavior necessitates environment-friendly methods of contaminants removal that drastically reduced the treatment cost and time. Proper processing methods such as calcination pretreatment combined with ultrasound-assisted leaching [15] that increase $\mathrm{SiO}_{2}$ content concentration up to $99.9 \%$ and methods using $\mathrm{HCl}-\mathrm{NH}_{4} \mathrm{Cl}$ and $\mathrm{H}_{2} \mathrm{SO}_{4}-\mathrm{NH}_{4} \mathrm{Cl}$ reagents with removal rate between 88 and $99 \mathrm{wt} \%$ for some impurities ( $\mathrm{Al}, \mathrm{K}$ and $\mathrm{Fe}$ ) have been developed [16] to upgrade quartz purity in order to meet industries' quartz glass requirements. In this regard, industries often prefer the application of purification techniques in medium- to high-purity resources.

In southwestern Cameroon, quartzitic rocks and quartz veins occur along major fault/shear zones and metamorphic rocks. The fault rocks range from breccias to mylonites, and most of them are monomineralic composed essentially of milky to transparent quartz. The potential of finding HPQ in these rocks has not been evaluated despite the widespread occurrence of these lithologies in the area. This is the aspect that constitutes the rationale of this study, and the expected results are of more than local importance considering that the potential of finding $\mathrm{HPQ}$ in the area exists.

\section{Geological setting}

\subsection{Regional geological setting}

Etam area is located in the southwestern sector of the Tombel Plain and belongs to the central domain of the Central African Fold Belt (CAFB) [17-19] in the southwest
Fig. 1 Location of study area: a continental structures of Western Gondwana after Pan-African tectonic evolution (modified after Njome and Dewit [42]). Shear Zones: CCSZ (Central Cameroon Shear Zone); (SF) Sanaga Fault; (TBF) Tchollire-banyo Fault; (Pe) Pernambuco Fault; (Pa) Patos Fault. b Geological map of Cameroon (modified after Toteu et al. [18]). The Central Cameroon Shear Zone is defined by a system of NE-trending faults comprising TchollireBanyo Fault (TBF), Adamawa Fault (AF), Sanaga Fault (SF), and KribiCampo Fault (KCF). NWC, Northwestern Cameroon domain; AYD, Adamawa-Yade Domain; YD, Yaounde Domain. c Geologic map of the study area

region of Cameroon. The CAFB is a megastructure, generally $\mathrm{E}-\mathrm{W}$ oriented, and it is about $5000 \mathrm{~km}$ in length and about $300 \mathrm{~km}$ in width (Fig. 1a), running through Cameroon across the Atlantic Ocean into northeast of Brazil [20-25]. The central domain of CAFB in Cameroon comprises the Paleoproterozoic granulite $[18,26-28]$ and the Neoproterozoic metasedimentary rocks [29-31] intruded by syntectonic granitoids [25, 32-39] along thrust and shear zones (Fig. 1b), the most prominent being the Central Cameroon Shear Zone (CCSZ). The CCSZ is one of the most important and largest active strike-slip fault zones in Cameroon. It is part of the transatlantic shear zone system referred to as the Central African Shear zone (CASZ) that extends from the interior of Africa across the Atlantic into South America [40]. It is a set of anastomosing transcurrent faults [41] and shows an important mylonitic band trending $N 70^{\circ} \mathrm{E}$ to $\mathrm{N} 30^{\circ} \mathrm{E}$.

\subsection{Geology of Etam}

The Etam area has mainly plutonic rocks (granitic and granodioritic) and metamorphic rocks including gneisses and migmatites. These lithologies are associated with a mylonitic band (Fig. 1c) oriented N030 to N045 [43] termed the Etam shear zone (ESZ) [44], which constitutes a segment of CCSZ. The mylonitization event has been attributed to a Pan-African age [40] and has reworked the gneissic foliation. The basement rocks at Etam are extensively covered in some places by the basaltic lavas from the Cameroon Volcanic Line (CVL). All these lithologic units are crosscut by several randomly oriented fracture sets and quartz veins. The quartz veins are few millimeters to several meters wide.

The studied quartz veins in this work are observed in ESZ. This is a clear white rock with no other rock-forming minerals than quartz similar to the Serra de Santa Helena high-purity quartz rock. $[43,44]$ suggested magmatic protoliths for the mylonitic rocks in Etam. These previous studies also indicated greenschist to amphibolitic metamorphic conditions between 300 and $450{ }^{\circ} \mathrm{C}$ in the surrounding country rocks, where epidote, neocrystallized quartz and chlorite minerals assemblage coupled with 


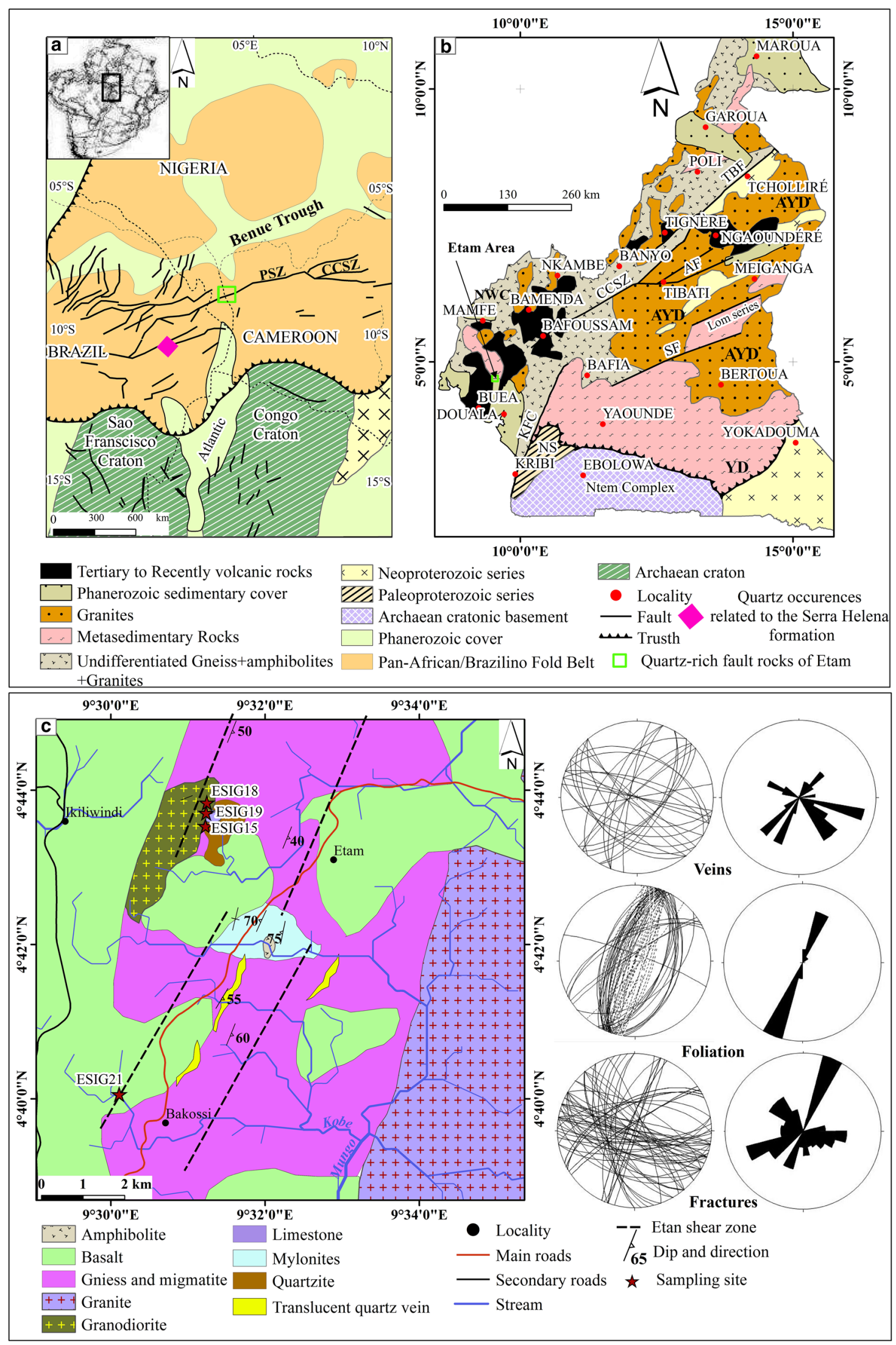


the albitization of K-feldspar and the formation of perthite were recorded.

The ESZ surrounding rock or wall rock (granodiorite) shows magmatic constituents $\left(\mathrm{Kfs}_{1}, \mathrm{Qtz}_{1}, \mathrm{Pl}_{1}\right.$ and $\left.\mathrm{Bt}_{1}\right)$, recrystallized quartz $\left(\mathrm{Qtz}_{2}\right)$ and $\mathrm{Ab}+\mathrm{Chl}$ as products of $\mathrm{Kfs}_{1}$ alteration. The mylonites in the ductile zone in addition to primary igneous minerals also have secondary constituents $\left(\mathrm{Qtz}_{2}, \mathrm{Qtz}_{3}, \mathrm{Pl}_{2}, \mathrm{Bt}_{2}, \mathrm{Ms}\right)$ developed at the expense of $\mathrm{Qtz}_{1}, \mathrm{Pl}_{1}$ and $\mathrm{Bt}_{1}$ through pervasive alteration and recrystallization. Other minerals include amphibole, muscovite, chlorite as well as iron oxide, pyrite and zircon. According to [44], the pervasive alteration in ESZ released $\mathrm{K}^{+}, \mathrm{Na}^{+}$, $\mathrm{Ca}^{+}, \mathrm{Fe}^{+}$and $\mathrm{Al}^{+}$ions that circulated in hydrothermal fluids saturated in $\mathrm{Si}$, precipitated in fractures and enriched the quartz veins.

For this study, two quartz veins were mapped and suitable quartz samples were collected for systematic laboratory analyses as detailed in the following sections.

\section{Methods}

\subsection{Fluid inclusion observation using optical microscopy}

For the fluid inclusion observation, a small amount of quartz grains sized 70 to $180 \mu \mathrm{m}$ was placed on a microscope slide. In order to improve the observation of the grains, a film of kerosene was applied over them. The kerosene has a refractive index similar to that of the silica, which reduces undesired surface observations. A Nikon optical microscope operated at $500 \times$ magnifications was used to acquire transmitted light photographs for fluid inclusion analysis, using a Nikon digital camera. All photographs were taken at room temperature. Using this methodology, it was possible to obtain insights on the nature of the fluid and mineral inclusions present in the grains. Although more complete analyses were not carried out, regarding homogenization temperature and other key properties of the inclusions, it was possible to obtain reliable data on mineral inclusions in the quartz grains. These data were vital in order to propose insights into the genesis of veins.

\subsection{Fusion over silica plate}

Samples were powdered using a silica mortar and sieved in nylon sieves at the Analytical Geochemistry Laboratory, UNICAMP, Brazil. Particle size distribution was selected between 80 and 200 mesh, i.e., 75 to $180 \mu \mathrm{m}$. The manufactured powders were then placed over a silica plate, and a $\mathrm{H}_{2} / \mathrm{O}_{2}$ flame was applied over it using a premix torch. Flame conditions, burner distance to the sample and time of fusion were kept the same during all experiments, about $4 \mathrm{~mm}$ and $15 \mathrm{~s}$, respectively, although samples took different times until complete fusion. For bubble analysis, the silica plates were photographed using a mineralogical microscope. Photographs of each fused plate were taken and then processed by computational analysis, in order to measure average bubble size and density on each photograph. This is a common test conducted by several silica glass industries in order to evaluate the powder performance during glass making. Bubbles larger than 10 to $15 \mu \mathrm{m}$ are highly undesired once they can affect the final glass properties. This procedure is widely used in the literature $[10-13,45]$.

\subsection{Chemical analysis using inductively coupled plasma mass spectroscopy (ICP-MS) on quartz}

Quartz samples of $0.1 \mathrm{~g}$ were dissolved using $0.5 \mathrm{~mL}$ of distilled HF in special vessels. The samples were then kept over a hot plate at $80^{\circ} \mathrm{C}$ for $1 \mathrm{~h}$ in order to enhance the dissolution process. Afterward, temperature was elevated to $110^{\circ} \mathrm{C}$ for evaporation. Subsequently, $0.5 \mathrm{~mL}$ of $\mathrm{HF}$ and $0.1 \mathrm{~mL}$ of $\mathrm{HNO}_{3}$ were added and the system was kept closed for $24 \mathrm{~h}$. After this procedure, the samples were recovered using a nitric acid solution of $1 \%$ in mass. All solutions were prepared using ultrapure water $(18.2 \mathrm{M} \Omega \mathrm{cm})$ obtained by Mili-Q system. All used acids were purified by subboiling. The vessels used were previously cleaned with a $5 \%$ nitric acid solution and washed with ultrapure water. All measurements were conducted by the ICP-MS technique using an X series II (Thermo) instrument, equipped with collision cell technology (CCT) at the Analytical Geochemistry Laboratory, Institute of Geosciences, UNICAMP, Brazil [45].

\subsection{Chemical analysis using laser ablation inductively coupled plasma mass spectroscopy (LA-ICP-MS)}

Quartz composition was further evaluated using a New Wave Research Excimer Laser Ablation UP193FX and an Agilent 7500i quadrupole mass spectrometer. The laser had a pulse rate of $20 \mathrm{~Hz}$, a speed of $15 \mu \mathrm{m} \mathrm{s}^{-1}$, a spot size of $50 \mu \mathrm{m}$ and energy fluency of $5-7 \mathrm{~mJ} \mathrm{~cm}^{-2}$ on the sample surface. Raster ablation was applied on an area of approximately $150 \mu \mathrm{m} \times 300 \mu \mathrm{m}$. The approximate depth of ablation was about $50 \mu \mathrm{m}$. The carrier gas for transport of the ablated material to the ICP-MS was He mixed with Ar. External calibration was performed using three silicate glass reference materials produced by the National 
Institute of Standards and Technology, USA (NIST SRM 610, 612 and 614). In addition, the NIST SRM 1830 soda-lime float glass $\left(0.1 \% \mathrm{~m} / \mathrm{m} \mathrm{Al}^{2} \mathrm{O}_{3}\right)$, the certified reference material BAM No. 1 amorphous $\mathrm{SiO}_{2}$ glass and the Qz-Tu synthetic pure quartz monocrystal were used. Measurements on commercially available IOTA HPQ material as well as reference material BSC CRM 313/1 (high-purity quartz) were performed for further external calibration; reproducibility and accuracy. Each measurement comprised 15 scans of each isotope, with a measurement time varying from a $0.15 \mathrm{~s} / \mathrm{scan}$ for $\mathrm{K}$ in high resolution to a $0.024 \mathrm{~s} / \mathrm{scan}$ of, for example, $\mathrm{Li}$ in low resolution. A linear regression model, including several measurements of the different reference materials, was used to define the calibration curve for each element. For the calculation of $\mathrm{P}$ concentrations, the procedure of [46] was applied. Ten sequential measurements on the Qz-Tu synthetic pure quartz monocrystal standard were used to estimate the limits of detection (LOD- $3 \sigma$ of ten measurements). The analytical error ranges within $10 \%$ of the absolute concentration of the element.

\subsection{Mineralogical quantitative analysis of quartz samples by SEM-EDS}

Each quartz sample was crushed and panned in the laboratory. Grains were observed under a scanning electron microscope (SEM) fitted with an energy-dispersive spectrometer (EDS) following procedures described by [47]. The EDS provided geochemical patterns reminiscent of the chemical composition of each phase identified.

\section{Results and interpretation}

\subsection{Petrography and textural studies}

Two quartz bodies are studied in this work: (1) quartzite body, showing blocks with variable dimensions (up to $20 \mathrm{~m} \times 8 \mathrm{~m}$ ) observed in the Etam Shear Zone (ESZ). The quartzite blocks are brecciated and can be traced along strike for over $2.5 \mathrm{~km}$ [44] in NNE-SSW to NE-SW direction. On some large blocks, joints and hydrothermal quartz veinlets (up to $15 \mathrm{~cm}$ wide) are observed arranged in subparallel arrays (Fig. 2a). The veinlets are characterized by a development of recrystallized serrate to elongated blocky quartz grains, where crystals grow from the wall inward (Fig. 2b). Generally, the blocks are monomineralic constituted by milky quartz clasts showing variable dimensions ( $<0.2 \mathrm{~mm}$ to $8 \mathrm{~cm}$ in size) and having the form of polygonal crystals with sharp edges (Fig. 2c). Some are elongated and faceted, healed by a silicified quartz matrix (i.e., an optically continuous silica mass), composed of fine quartz crystals $(10-80 \mu \mathrm{m})$ showing in some places red spots
(Fig. 2d) of clustered grains (colored material), probably Fe-stained quartz grains trapped within an aggregate of smaller quartz grains.

Two types of breccias are observed in the Etam samples, both in hand specimen and under the microscope (see Table 1 for samples description): (a) Crackle breccias ( $75-100 \%$ clast ' $2 \mathrm{~mm}$, Fig. 2e) display small isolated monomineralic quartzite blocks $(1.2 \times 0.8 \mathrm{~m})$ and represent $\sim 5 \%$ of the quartzite in the area. They contain from $\sim 85$ to $~ 98 \%$ angular clasts with sharp edges, variable dimensions ( $2 \mathrm{~mm}$ to $8 \mathrm{~cm}$, Fig. 2c) and a siliceous matrix often less than $3 \%$. (b) Mosaic breccias (65-75\% clast' $2 \mathrm{~mm}$, Fig. $2 \mathrm{f}$ ) which show blocks (up to $20 \times 12 \mathrm{~m}$ ) and are also monomineralic are widely spread in the study area, composed of slightly elongated quartz clasts $(0.6 \mathrm{~mm}$ to $1.2 \mathrm{~cm}$ ) and occupy $65-73 \%$ of the volume of the rock. Some wider intergranular zones are observed with very fine-grained cataclasite indicating sintered material. In some samples, fine-grained materials of the reformed grains show interlocking grain boundaries in some thin sections. (2) A translucent quartz vein $(\sim 20 \mathrm{~cm}$ wide, Fig. $2 \mathrm{~g}$ ) was mapped in the southwestern sector of the study area surrounded by a biotite gneiss country rock. The regional foliation and the vein are parallel and trend $\mathrm{N} 023^{\circ} \mathrm{E}$ to $\mathrm{N} 030^{\circ} \mathrm{E}$ with subvertical dips. The vein is composed of highly homogeneous translucent fine-grained pure quartz (Fig. $2 \mathrm{~h}$ ) and ranges from 1 to $3 \mu \mathrm{m}$ in size. Fluid and mineral inclusions are observed in both deposits, and a detailed description of their petrographic characteristics is provided in the paragraph on fluid inclusions below.

\subsection{Geochemistry of Etam quartz}

\subsubsection{Rock geochemistry by ICP-MS}

The bulk rock chemistry of the Etam quartz samples is displayed in Table 2. The samples are characterized by 98.26-99.75 wt $\% \mathrm{SiO}_{2}$. The concentrations of the other major elements are very low $\left(\mathrm{Al}_{2} \mathrm{O}_{3}=0.01\right.$ to $0.15 \mathrm{wt} \%$, $\mathrm{Fe}_{2} \mathrm{O}_{3}$ tot $=0.1$ to $0.59 \mathrm{wt} \%, \mathrm{MgO}=0.01$ to $0.02 \mathrm{wt} \%$, $\mathrm{TiO}_{2}=0.002$ to $0.006 \mathrm{wt} \% \mathrm{Na}_{2} \mathrm{O}=0.01$ to 0.02 ). The concentration of $\mathrm{K}_{2} \mathrm{O}(0.01 \mathrm{wt} \%)$ is constant. Most of the trace elements are below the detection limit. When present, their concentrations are low, e.g., $\mathrm{Cr}$ (55-220 ppm), Zr (3-4 ppm) and $\mathrm{Ba}$ (3-4 ppm).

Only four light rare-earth elements (LREE) are detected by the ICP-MS analysis. Their concentrations vary slightly: La (0.2 to $0.4 \mathrm{ppm}), \mathrm{Ce}(0.3$ to $0.4 \mathrm{ppm}), \operatorname{Pr}(0.03$ to $0.05 \mathrm{ppm}$ ) and $\mathrm{Nd}(0.1$ to $0.2 \mathrm{ppm}$. The quasi-totality of heavy rare-earth elements (HREE) is below detection limits. 
Fig. 2 Photograph and photomicrograph of the Etam quartz. a Brecciated quartzite block crosscut by quartz veinlets in subparallel array, $\mathbf{b}$ recrystallized quartz grain growing from the wall inward in quartz vein c milky quartz clast, faceted and elongated, up to $12 \mathrm{~cm}$. d photomicrograph of cluster of small quartz grain containing red spot, probably iron oxide, e crackle breccia, f mosaic breccia, $\mathbf{g}$ aspect of translucent quartz vein translucent quartz vein on the outcrop (yellow lines), $\mathbf{h}$ hand specimen of the translucent quartz vein
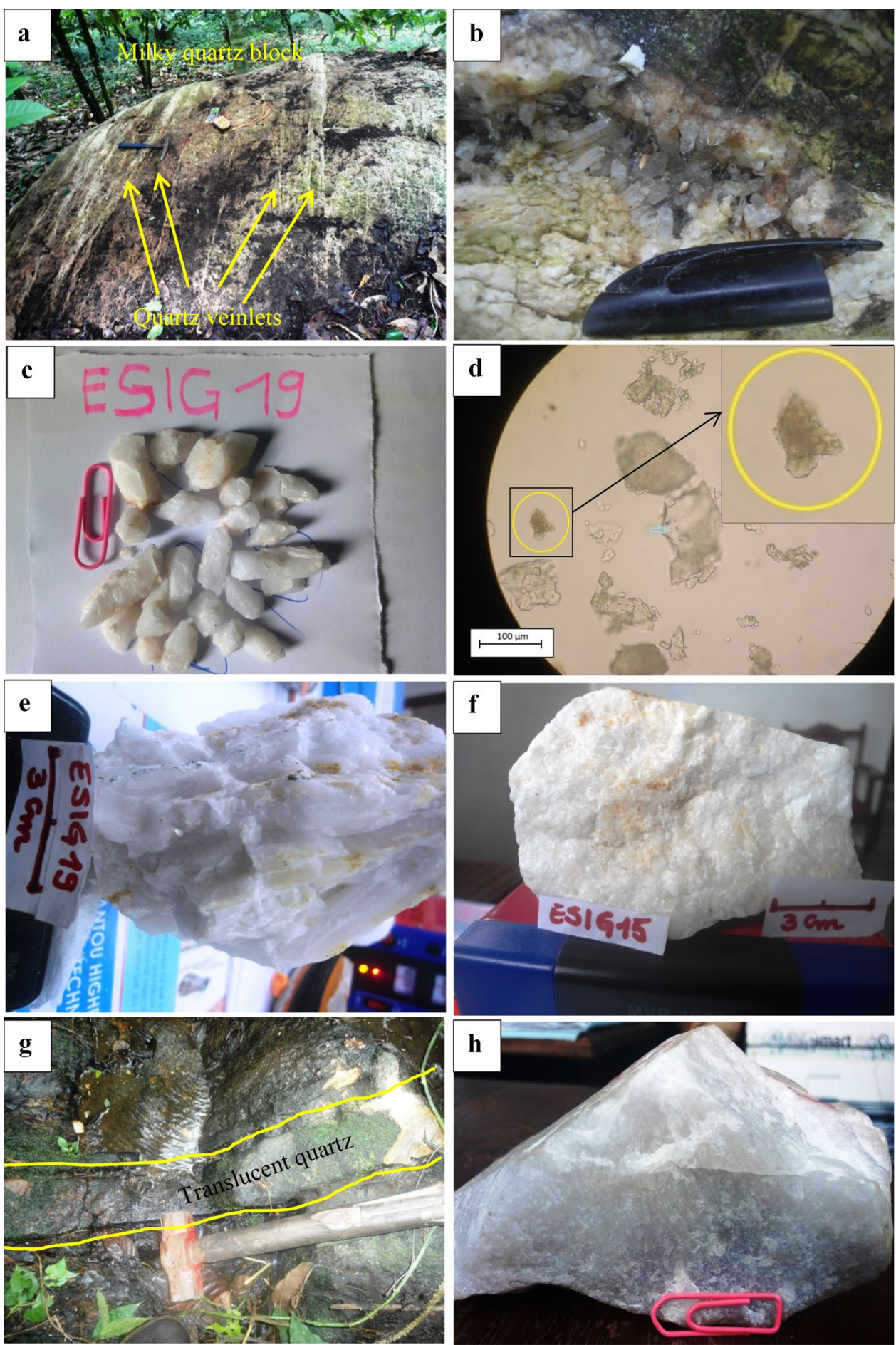

\subsubsection{Concentrations of impurities in the quartz determined by LA-ICP-MS}

The analysis of representative quartz samples is given in Table 3. Three samples were selected from the brecciated quartz block (milky quartz) and two samples from the translucent quartz vein. A single spot was analyzed in each sample section. In order to better appreciate the chemical purity of quartz, the elements' concentrations were converted into $\mu \mathrm{g} \mathrm{g}^{-1}$. The data illustrated that: (1) milky quartz (samples ESIG15, ESIG18 and ESIG19) has high to moderately high concentrations of trace elements compared to average concentrations in natural quartz $[6,14]$ : Al (mean $579.66 \mu \mathrm{g} \mathrm{g}^{-1}$ ), Ca (mean $70.7 \mu \mathrm{g} \mathrm{g}^{-1}$ ), Fe (mean $\left.57.36 \mu \mathrm{g} \mathrm{g}^{-1}\right), \mathrm{K}\left(\right.$ mean $\left.116.96 \mu \mathrm{g} \mathrm{g}^{-1}\right)$, Ti (mean $\left.5.67 \mu \mathrm{g} \mathrm{g}^{-1}\right)$, and low concentration for $\mathrm{Zr}$ (mean $0.26 \mu \mathrm{g} \mathrm{g}^{-1}$ ) Ce (mean

\section{SN Applied Sciences}


Table 1 Representative investigated samples description

\begin{tabular}{lll}
\hline Sample no. & Sample description & Inclusion types \\
\hline ESIG15 & $\begin{array}{c}\text { Averagely cohesive, crackle breccia, medium-size milky } \\
\text { quartz clasts healed by very fine grains of siliceous matrix } \\
\text { ESIG18 }\end{array}$ & $\begin{array}{c}\text { Monophase, irregular and regular two-phase inclusion, mineral } \\
\text { inclusion }\end{array}$ \\
bSIG19 & $\begin{array}{c}\text { Weakly cohesive, crackle breccias with milky large quartz } \\
\text { clasts (up to } 8 \mathrm{~cm}) \text { often brittle + siliceous matrix }\end{array}$ & $\begin{array}{c}\text { Cubic crystal inclusion, irregular two-phase and cluster inclu- } \\
\text { sions, mineral and satellite inclusions } \\
\text { Dipyramidal monophasic and hexagonal negative crystal two- } \\
\text { phase inclusions, mineral inclusion }\end{array}$ \\
ESIG21a & Massive, fine translucent quartz grains & $\begin{array}{c}\text { Small inclusions, oriented biphasic negative crystal type, } \\
\text { dipyramidal monophasic fluid inclusion, needle-like mineral } \\
\text { inclusions }\end{array}$ \\
& &
\end{tabular}

$0.21 \mu \mathrm{g} \mathrm{g}^{-1}$ ) and $\mathrm{Ge}$ (mean $0.14 \mu \mathrm{g} \mathrm{g}^{-1}$ ). (2). The translucent quartz is characterized by low concentrations of trace elements compared to milky quartz: Al (mean $107 \mu \mathrm{g} \mathrm{g}^{-1}$ ), $\mathrm{Ca}\left(\right.$ mean $\left.27.85 \mu \mathrm{g} \mathrm{g}^{-1}\right), \mathrm{Cr}$ (mean $3.54 \mu \mathrm{g} \mathrm{g}^{-1}$ ), Fe (mean $\left.26.05 \mu \mathrm{g} \mathrm{g}^{-1}\right)$, Ge $\left(\right.$ mean $\left.0.83 \mu \mathrm{g} \mathrm{g}^{-1}\right), \mathrm{K}\left(\right.$ mean $\left.82,4 \mu \mathrm{g} \mathrm{g}^{-1}\right)$, $\mathrm{Li}\left(\right.$ mean $\left.0.51 \mathrm{\mu g} \mathrm{g}^{-1}\right), \mathrm{Mg}$ (mean $5.15 \mu \mathrm{g} \mathrm{g}^{-1}$ ), $\mathrm{Na}$ (mean $\left.34.75 \mu \mathrm{g} \mathrm{g}^{-1}\right)$, Ni (mean $\left.1.84 \mu \mathrm{g} \mathrm{g}^{-1}\right)$, Ti (mean $\left.23.75 \mu \mathrm{g} \mathrm{g}{ }^{-1}\right)$, $\mathrm{Zr}\left(\right.$ mean $1.61 \mu^{-1}$ g g ${ }^{-1}$ In Etam quartz, Al, Ca, $\mathrm{Cr}, \mathrm{Fe}, \mathrm{K}, \mathrm{Mg}$, $\mathrm{Na}, \mathrm{Ni}, \mathrm{Ti}$ and $\mathrm{Zr}$ represent about $99 \%$ of the total impurities in this quartz. Other elements are below the detection limits. In HPQ, Fe is desirable to be under $10 \mathrm{ppm}$ and $\mathrm{Ca}$ below $10 \mathrm{ppm}$ as well. All the trace elements in HPQ put together should be less than $50 \mathrm{ppm}[6,14]$.

In the translucent quartz, the concentration of trace elements is low compared to the milky quartz. An exception is observed for $\mathrm{Ag}, \mathrm{Co}, \mathrm{Cr}, \mathrm{Ni}, \mathrm{Zn}, \mathrm{Zr}$ and $\mathrm{Ti}$. Aluminum is the most important impurity in this quartz, and it is highly variable (107-811 $\mathrm{g} \mathrm{g}^{-1}$ ) between samples (Table 3). It commonly substitutes $\mathrm{Si}$ in quartz structure or is incorporated in quartz by the hydrothermal fluids. Titanium concentration is consistently higher in translucent quartz compared to Ti in milky quartz. The variability of Ti concentrations between milky and translucent quartz is probably related to the difference in deformation temperature or the presences of mineral inclusions $[48,49]$. Indeed, microscopic studies of translucent quartz permit to observe several rutile mineral inclusions in translucent quartz, which increase their bulk (whole rock) Ti concentration [50]. Potassium content is highly variable in milky quartz. Sample E-SIG19 shows K concentration below the detection limit, and in sample ESIG15, the K content is 261 in $\mu \mathrm{g} \mathrm{g}^{-1}$. The concentration of $\mathrm{Na}$ in both quartz varieties is reflected by the presence of several cubic salt crystals $(\mathrm{NaCl})$ within fluid inclusions (daughter crystals) observed under the microscope. The calcium and $\mathrm{Mg}$ contents are high in all the samples and variable $(\mathrm{Ca} / \mathrm{Mg}$ ratio varies between from 2.03 to 16.36). Usually, the concentration of these elements is related to mineral inclusions in the quartz crystals or halite phases in the fluid inclusions [11, $14,51,52]$ reflecting the crystallization of quartz in saline environments $[11,51,53]$. The concentration of $\mathrm{Fe}$ is high in all samples. According to [6], the high concentrations of Fe in quartz are predominantly diffusion-controlled. Therefore, ferromagnesian minerals in contact with quartz can induce high Fe content in this quartz. Microscopic observation permitted to distinguish spots of Fe-rich mineral inclusions in quartz grains attesting the accumulation of $\mathrm{Fe}$ in the milieu. Lithium shows low concentration (mean

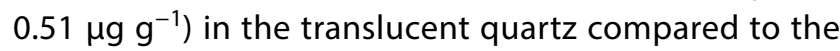
milky quartz (mean $6.79 \mu \mathrm{g} \mathrm{g}^{-1}$ ), thus suggesting that $\mathrm{Li}$ is probably associated with submicroscopic mineral inclusions in the milky quartz [54]. This suggests therefore the low participation of $\mathrm{Li}$ in the process of charge-balancing cation for $\mathrm{Al}$, Fe and $\mathrm{P}$. Therefore, the $\mathrm{H}^{+}$from the hydrothermal fluid plays a greater role in the charge compensator for cation in the translucent quartz. SEM/EDS analyses were conducted to better understand the aspects of possible mineral inclusions in the translucent quartz, once the whole rock analysis and the fusion tests indicated that this quartz variety is the most promising. Two points $\left(P_{1}\right.$ and $P_{2}$ ) were selected in sample ESIG21a (Fig. 3a) and three $\left(P_{1}, P_{2}\right.$ and $\left.P_{3}\right)$ in sample ESIG21b (Fig. 3b). The resulting EDS spectra for samples ESIG 21a [Fig. 3a, ESIG21a $\left(P_{1}\right)$ and $\left(P_{2}\right)$ ] and ESIG 21b (Fig. 3b, ESIG21b $\left(P_{1}\right),\left(P_{2}\right)$ and $\left(P_{3}\right)$ show high peaks for $\mathrm{O}$ and $\mathrm{Si}$. The absence of any peaks for other elements that could have been contributed by submicroscopic or nanoparticle mineral inclusions indicated that this quartz variety is free of contaminant mineral inclusions.

\subsection{Fluid inclusion petrography}

Fluid inclusions observed in the Etam quartz samples generally are monophase or two-phase inclusions (Table 1). In this study, the fluid inclusions for the milky quartz samples are studied and the results presented separately from the data derived from samples of the translucent quartz. 
Table 2 Major, trace and rare-earth element analyses of Etam quartzite (ICP-MS)

\begin{tabular}{|c|c|c|c|c|c|c|c|c|c|c|}
\hline & \multicolumn{8}{|c|}{ Milky quartz } & \multicolumn{2}{|c|}{ Translucent quartz } \\
\hline & ESIG 5 & ESIG 10 & ESIG 14 & ESIG 15a & ESIG 15b & ESIG $15 c$ & ESIG 18 & ESIG 19 & ESIG 21a & ESIG 21b \\
\hline \multicolumn{11}{|c|}{ Major elements (wt\%) } \\
\hline $\mathrm{SiO}_{2}$ & 99.75 & 98.67 & 98.99 & 98.26 & 98.26 & 99.21 & 99.4 & 99.58 & 98.46 & 98.46 \\
\hline $\mathrm{Al}_{2} \mathrm{O}_{3}$ & 0.03 & 0.13 & 0.02 & 0.13 & 0.13 & 0.11 & 0.05 & 0.05 & 0.05 & 0.05 \\
\hline $\mathrm{Fe}_{2} \mathrm{O}_{3}$ & 0.1 & 0.39 & 0.51 & 0.49 & 0.49 & 0.32 & 0.36 & 0.21 & 0.58 & 0.58 \\
\hline $\mathrm{MnO}$ & 0.006 & 0.005 & 0.006 & 0.005 & 0.005 & 0.005 & 0.006 & 0.006 & 0.006 & 0.006 \\
\hline $\mathrm{MgO}$ & 0.02 & 0.01 & 0.02 & 0.01 & 0.01 & 0.01 & 0.02 & 0.02 & 0.02 & 0.02 \\
\hline $\mathrm{CaO}$ & 0.02 & 0.02 & 0.02 & 0.02 & 0.02 & 0.02 & 0.02 & 0.01 & 0.02 & 0.02 \\
\hline $\mathrm{Na}_{2} \mathrm{O}$ & 0.02 & 0.01 & 0.02 & 0.01 & 0.01 & 0.01 & 0.02 & 0.02 & 0.02 & 0.02 \\
\hline $\mathrm{K}_{2} \mathrm{O}$ & 0.01 & 0.01 & 0.01 & 0.01 & 0.01 & 0.01 & 0.01 & 0.01 & 0.01 & 0.01 \\
\hline $\mathrm{TiO}_{2}$ & 0.004 & 0.002 & 0.006 & 0.002 & 0.002 & 0.002 & 0.005 & 0.006 & 0.006 & 0.006 \\
\hline $\mathrm{P}_{2} \mathrm{O}_{5}$ & $<0.01$ & $<0.01$ & $<0.01$ & $<0.01$ & $<0.01$ & $<0.01$ & $<0.01$ & $<0.01$ & $<0.01$ & $<0.01$ \\
\hline LOI & 0.04 & 0.25 & 0.02 & 0.25 & 0.25 & 0.25 & 0.01 & 0.07 & 0.07 & 0.07 \\
\hline Total & 100 & 99.50 & 99.622 & 99.187 & 99.19 & 99.947 & 99.901 & 99.982 & 99.25 & 99.242 \\
\hline \multicolumn{11}{|c|}{ Trace elements (ppm) } \\
\hline $\mathrm{Be}$ & $<1$ & $<1$ & $<1$ & $<1$ & $<1$ & $<1$ & $<1$ & $<1$ & $<1$ & $<1$ \\
\hline Sc & $<1$ & $<1$ & $<1$ & $<1$ & $<1$ & $<1$ & $<1$ & $<1$ & $<1$ & $<1$ \\
\hline V & $<5$ & $<5$ & $<5$ & $<5$ & $<5$ & $<5$ & $<5$ & $<5$ & $<5$ & $<5$ \\
\hline $\mathrm{Cr}$ & 220 & 55 & 94 & 100 & 100 & 81 & 199 & 216 & 220 & 220 \\
\hline Co & $<1$ & $<1$ & $<1$ & $<1$ & $<1$ & $<1$ & $<1$ & $<1$ & $<1$ & $<1$ \\
\hline $\mathrm{Ni}$ & $<20$ & $<20$ & $<20$ & $<20$ & $<20$ & $<20$ & $<20$ & $<20$ & $<20$ & $<20$ \\
\hline $\mathrm{Cu}$ & $<10$ & $<10$ & $<10$ & $<10$ & $<10$ & $<10$ & $<10$ & $<10$ & $<10$ & $<10$ \\
\hline $\mathrm{Zn}$ & $<30$ & $<30$ & $<30$ & $<30$ & $<30$ & $<30$ & $<30$ & $<30$ & $<30$ & $<30$ \\
\hline Ga & $<1$ & $<1$ & $<1$ & $<1$ & $<1$ & $<1$ & $<1$ & $<1$ & $<1$ & $<1$ \\
\hline $\mathrm{Ge}$ & 1 & $<0.5$ & 1 & $<0.5$ & $<0.5$ & 1 & 1 & 1 & 1 & 1 \\
\hline As & $<5$ & $<5$ & $<5$ & $<5$ & $<5$ & $<5$ & $<5$ & $<5$ & $<5$ & $<5$ \\
\hline $\mathrm{Rb}$ & $<1$ & $<1$ & $<1$ & $<1$ & $<1$ & $<1$ & $<1$ & $<1$ & $<1$ & $<1$ \\
\hline $\mathrm{Sr}$ & $<2$ & $<2$ & $<2$ & $<2$ & $<2$ & $<2$ & $<2$ & $<2$ & $<2$ & $<2$ \\
\hline Y & $<0.5$ & $<0.5$ & $<0.5$ & $<0.5$ & $<0.5$ & $<0.5$ & $<0.5$ & $<0.5$ & $<0.5$ & $<0.5$ \\
\hline $\mathrm{Zr}$ & 3 & 4 & 4 & 4 & 4 & 3 & 3 & 4 & 3 & 3 \\
\hline $\mathrm{Nb}$ & 4.1 & 5.1 & 4.7 & 5.4 & 5.4 & 3.9 & 3.1 & 3.1 & 3.1 & 3.1 \\
\hline Mo & $<2$ & $<2$ & $<$ & 10 & 10 & $<2$ & $<2$ & 8 & $<2$ & $<2$ \\
\hline $\mathrm{Ag}$ & $<0.5$ & $<0.5$ & $<0.5$ & $<0.5$ & $<0.5$ & $<0.5$ & $<0.5$ & $<0.5$ & $<0.5$ & $<0.5$ \\
\hline In & $<0.1$ & $<0.1$ & $<0.1$ & $<0.1$ & $<0.1$ & $<0.1$ & $<0.1$ & $<0.1$ & $<0.1$ & $<0.1$ \\
\hline Sn & $<1$ & $<1$ & $<1$ & $<1$ & $<1$ & $<1$ & $<1$ & $<1$ & $<1$ & $<1$ \\
\hline $\mathrm{Sb}$ & $<0.2$ & $<0.2$ & $<0.2$ & $<0.2$ & $<0.2$ & $<0.2$ & $<0.2$ & $<0.2$ & $<0.2$ & $<0.2$ \\
\hline Cs & $<0.1$ & $<0.1$ & $<0.1$ & $<0.1$ & $<0.1$ & $<0.1$ & $<0.1$ & $<0.1$ & $<0.1$ & $<0.1$ \\
\hline $\mathrm{Ba}$ & 4 & 3 & 3 & 4 & 4 & 4 & 4 & 3 & 4 & 4 \\
\hline $\mathrm{Hf}$ & $<0.1$ & $<0.1$ & $<0.1$ & $<0.1$ & $<0.1$ & $<0.1$ & $<0.1$ & $<0.1$ & $<0.1$ & $<0.1$ \\
\hline Ta & $<0.01$ & $<0.01$ & $<0.01$ & $<0.01$ & $<0.01$ & $<0.01$ & $<0.01$ & $<0.01$ & $<0.01$ & $<0.01$ \\
\hline W & $<0.5$ & $<0.5$ & $<0.5$ & $<0.5$ & $<0.5$ & $<0.5$ & $<0.5$ & $<0.5$ & $<0.5$ & $<0.5$ \\
\hline $\mathrm{TI}$ & $<0.05$ & $<0.05$ & $<0.05$ & $<0.05$ & $<0.05$ & $<0.05$ & $<0.05$ & $<0.05$ & $<0.05$ & $<0.05$ \\
\hline $\mathrm{Pb}$ & $<5$ & $<5$ & $<5$ & $<5$ & $<5$ & $<5$ & $<5$ & $<5$ & $<5$ & $<5$ \\
\hline $\mathrm{Bi}$ & $<0.1$ & $<0.1$ & $<0.1$ & $<0.1$ & $<0.1$ & $<0.1$ & $<0.1$ & $<0.1$ & $<0.1$ & $<0.1$ \\
\hline Th & $<0.05$ & $<0.05$ & $<0.05$ & $<0.05$ & $<0.05$ & $<0.05$ & $<0.05$ & $<0.05$ & $<0.05$ & $<0.05$ \\
\hline$\underline{U}$ & $<0.01$ & $<0.01$ & $<0.01$ & $<0.01$ & $<0.01$ & $<0.01$ & $<0.01$ & $<0.01$ & $<0.01$ & $<0.01$ \\
\hline \multicolumn{11}{|c|}{ Rare-earth element (ppm) } \\
\hline La & 0.4 & 0.2 & 0.3 & 0.2 & 0.2 & 0.3 & 0.4 & 0.4 & 0.4 & 0.4 \\
\hline
\end{tabular}


Table 2 (continued)

\begin{tabular}{|c|c|c|c|c|c|c|c|c|c|c|}
\hline \multicolumn{11}{|c|}{ Rare-earth element (ppm) } \\
\hline $\mathrm{Ce}$ & 0.3 & 0.4 & 0.4 & 0.4 & 0.4 & 0.3 & 0.4 & 0.4 & 0.4 & 0.4 \\
\hline $\operatorname{Pr}$ & 0.03 & 0.05 & 0.05 & 0.05 & 0.05 & 0.05 & 0.04 & 0.03 & 0.03 & 0.03 \\
\hline $\mathrm{Nd}$ & 0.2 & 0.2 & 0.2 & 0.2 & 0.2 & 0.1 & 0.2 & 0.1 & 0.1 & 0.1 \\
\hline Sm & $<0.01$ & $<0.01$ & $<0.01$ & $<0.01$ & $<0.01$ & $<0.01$ & $<0.01$ & $<0.01$ & $<0.01$ & $<0.01$ \\
\hline $\mathrm{Eu}$ & $<0.005$ & 0.01 & 0.01 & 0.01 & 0.01 & $<0.005$ & 0.01 & $<0.005$ & $<0.005$ & $<0.005$ \\
\hline Gd & $<0.01$ & $<0.01$ & $<0.01$ & $<0.01$ & $<0.01$ & $<0.01$ & $<0.01$ & $<0.01$ & $<0.01$ & $<0.01$ \\
\hline $\mathrm{Tb}$ & $<0.01$ & $<0.01$ & $<0.01$ & $<0.01$ & $<0.01$ & $<0.01$ & $<0.01$ & $<0.01$ & $<0.01$ & $<0.01$ \\
\hline Dy & $<0.01$ & $<0.01$ & $<0.01$ & $<0.01$ & $<0.01$ & $<0.01$ & $<0.01$ & $<0.01$ & $<0.01$ & $<0.01$ \\
\hline Ho & $<0.01$ & $<0.01$ & $<0.01$ & $<0.01$ & $<0.01$ & $<0.01$ & $<0.01$ & $<0.01$ & $<0.01$ & $<0.01$ \\
\hline Er & $<0.01$ & $<0.01$ & $<0.01$ & $<0.01$ & $<0.01$ & $<0.01$ & $<0.01$ & $<0.01$ & $<0.01$ & $<0.01$ \\
\hline Tm & $<0.005$ & $<0.005$ & $<0.005$ & $<0.005$ & $<0.005$ & $<0.005$ & $<0.005$ & $<0.005$ & $<0.005$ & $<0.005$ \\
\hline $\mathrm{Yb}$ & $<0.01$ & $<0.01$ & $<0.01$ & $<0.01$ & $<0.01$ & $<0.01$ & $<0.01$ & $<0.01$ & $<0.01$ & $<0.01$ \\
\hline $\mathrm{Lu}$ & $<0.002$ & $<0.002$ & $<0.002$ & $<0.002$ & $<0.002$ & $<0.002$ & $<0.002$ & $<0.002$ & $<0.002$ & $<0.002$ \\
\hline
\end{tabular}

\subsubsection{Milky quartz}

In the milky quartz, most of the fused grains contain abundant inclusions with small size (Fig. 4, yellow color) ranging from 2 to $12 \mu \mathrm{m}$ and randomly distributed (Fig. 5a). They are monophase or two-phase inclusions showing two distinct phases at room temperature: a solid daughter crystal phase and a fluid phase.

\section{- Monophase fluid inclusions}

The monophase fluid inclusions are fewer in number compared to the two-phase fluid inclusions. Rarely, they are dipyramidal monophasic inclusions (Fig. 5b, orange arrow). Most are irregular and some have the shape of negative crystals.

- Two-phase and three-phase fluid inclusions

The majority of fluid inclusions in the milky quartz are two-phase fluid inclusions. Usually, they are composed of liquid and gas although some have daughter crystals. The presence of halide crystals indicates that the liquid phase is probably brine while gas phase is $\mathrm{CO}_{2}$. Often here, fluid inclusions show spherical gas bubbles (Fig. 5 c, black arrows) with a range from 5 to $30 \%$ of the total volume of the inclusion. Many two-phase inclusions are irregular (Fig. 5c, black arrows) in shape. Smaller regular inclusions are observed with bubbles, often larger than the liquid volume (Fig. 5c, blue arrow). Some two-phase inclusions showing negative hexagonal crystal-shape (Fig. 5d, black arrow) are observed in this quartz.

Solid phases observed in the fluid inclusions mostly display cubic outlines (Fig. 5d, e, red arrow), which are probably salt crystals $(\mathrm{NaCl})$, as attested by the high amount of Na present in the ICP-MS data analysis (Table 3). Other fluid inclusions are rarely observed, mostly irregular in shape and larger $(12 \mu \mathrm{m})$ than the solid phases encountered in some inclusions (Fig. 5e, green arrow). Figure $5 f$ (blue light arrow) shows large inclusions with smaller fluid inclusions (satellite inclusions) surrounding it. Tarantola et al. $[55,56]$ showed that, due to deviatoric stress, inclusions can be deformed and dismembered, giving a large relic inclusion and a cluster of small neonate (satellite) inclusions around it.

\subsubsection{Translucent quartz}

The inclusions present in the translucent quartz are different from those of the milky quartz samples. The fluid inclusions are much smaller compared to those of milky quartz (Fig. 4) and oriented. Figure 6a shows this orientation (represented by the black line). Most of these oriented inclusions are of the negative crystal type but much smaller. Monophase inclusions are common and occur as dipyramidal monophase inclusions (Fig. 6b, orange arrow). Several needle-shaped mineral inclusions (Fig. 6c, gray arrow) which are suggested to be rutile because of the elevated concentration of Ti in LA-ICP-MS analyses (Table 3) are observed in this quartz sample as well as small acicular inclusions, randomly distributed in the grains.

\subsection{Fusion of quartz grains over silica plate: bubble formation and bubble characterization}

In this section, the results of the quartz/silica plates tested for bubble formation are presented in the form of photographs at various stages of heating. The images were then processed by computational analysis in order to measure average bubble size and bubble density on each 
Table 3 Impurities concentrations in quartz samples (LA-ICP-MS)

\begin{tabular}{|c|c|c|c|c|c|c|}
\hline & & \multicolumn{3}{|c|}{ Milky quartz } & \multicolumn{2}{|c|}{ Translucent quartz } \\
\hline & & ESIG15 & ESIG18 & ESIG19 & ESIG21a & ESIG21b \\
\hline $\mathrm{Ag}$ & $\mu \mathrm{g} \mathrm{g}^{-1}$ & 0.002 & 0.003 & 0.004 & 0.011 & 0.009 \\
\hline $\mathrm{Al}$ & $\mu \mathrm{g} \mathrm{g}^{-1}$ & 354 & 811 & 574 & 107 & 107 \\
\hline B & $\mu \mathrm{g} \mathrm{g}^{-1}$ & $<\mathrm{LD}$ & $<\mathrm{LD}$ & 51 & $<\mathrm{LD}$ & $<\mathrm{LD}$ \\
\hline $\mathrm{Ba}$ & $\mu \mathrm{g} \mathrm{g}^{-1}$ & 0.82 & 1.24 & 0.86 & 0.42 & 0.41 \\
\hline $\mathrm{Be}$ & $\mu \mathrm{g} \mathrm{g}^{-1}$ & 0.07 & 0.10 & 0.05 & 0.03 & 0.03 \\
\hline $\mathrm{Ca}$ & $\mu \mathrm{g} \mathrm{g}^{-1}$ & 64.3 & 47.8 & 100 & 27.3 & 28.4 \\
\hline $\mathrm{Ce}$ & $\mu \mathrm{g} \mathrm{g}^{-1}$ & 0.11 & 0.19 & 0.33 & 0.08 & 0.06 \\
\hline Co & $\mu \mathrm{g} \mathrm{g}^{-1}$ & 0.01 & 0.02 & 0.01 & 0.05 & 0.05 \\
\hline $\mathrm{Cr}$ & $\mu \mathrm{g} \mathrm{g}^{-1}$ & 0.85 & 1.46 & 1.49 & 3.43 & 3.65 \\
\hline Cs & $\mu \mathrm{g} \mathrm{g}^{-1}$ & 0.020 & 0.033 & 0.016 & 0.003 & 0.003 \\
\hline $\mathrm{Cu}$ & $\mu \mathrm{g} \mathrm{g}^{-1}$ & 0.30 & 0.23 & 0.88 & 0.52 & 0.62 \\
\hline Dy & $\mu \mathrm{g} \mathrm{g}^{-1}$ & 0.006 & 0.009 & 0.009 & 0.002 & 0.001 \\
\hline Er & $\mu \mathrm{g} \mathrm{g}^{-1}$ & 0.004 & 0.004 & 0.005 & 0.001 & 0.001 \\
\hline $\mathrm{Eu}$ & $\mu \mathrm{g} \mathrm{g}^{-1}$ & 0.001 & 0.003 & 0.003 & 0.001 & 0.001 \\
\hline $\mathrm{Fe}$ & $\mu \mathrm{g} \mathrm{g}^{-1}$ & 36.4 & 67.8 & 67.9 & 26.5 & 25.6 \\
\hline Ga & $\mu \mathrm{g} \mathrm{g}^{-1}$ & 0.06 & 0.15 & 0.05 & 0.02 & 0.02 \\
\hline $\mathrm{Gd}$ & $\mu \mathrm{g} \mathrm{g}^{-1}$ & 0.004 & 0.016 & 0.010 & 0.003 & 0.002 \\
\hline $\mathrm{Ge}$ & $\mu \mathrm{g} \mathrm{g}^{-1}$ & 0.15 & 0.12 & 0.17 & 0.83 & 0.84 \\
\hline $\mathrm{Hf}$ & $\mu \mathrm{g} \mathrm{g}^{-1}$ & 0.004 & 0.009 & 0.008 & 0.04 & 0.04 \\
\hline Ho & $\mu \mathrm{g} \mathrm{g}^{-1}$ & 0.001 & 0.001 & 0.002 & $<\mathrm{LD}$ & $<\mathrm{LD}$ \\
\hline K & $\mu \mathrm{g} \mathrm{g}^{-1}$ & 89.9 & 261 & $<\mathrm{LD}$ & 81.0 & 83.8 \\
\hline La & $\mu \mathrm{g} \mathrm{g}^{-1}$ & 0.07 & 0.36 & 0.11 & 0.04 & 0.04 \\
\hline $\mathrm{Li}$ & $\mu \mathrm{g} \mathrm{g}^{-1}$ & 5.24 & 11.4 & 3.74 & 0.51 & 0.51 \\
\hline Lu & $\mu \mathrm{g} \mathrm{g}^{-1}$ & 0.001 & $<\mathrm{LD}$ & 0.001 & $<\mathrm{LD}$ & $<\mathrm{LD}$ \\
\hline $\mathrm{Mg}$ & $\mu \mathrm{g} \mathrm{g}^{-1}$ & 6.78 & 23.5 & 6.11 & 5.64 & 4.67 \\
\hline $\mathrm{Mn}$ & $\mu \mathrm{g} \mathrm{g}^{-1}$ & 0.28 & 0.53 & 0.51 & 0.43 & 0.55 \\
\hline $\mathrm{Na}$ & $\mu \mathrm{g} \mathrm{g}^{-1}$ & 37.2 & 32.3 & 41.0 & 34.7 & 34.8 \\
\hline $\mathrm{Nb}$ & $\mu \mathrm{g} \mathrm{g}^{-1}$ & 0.04 & 0.04 & 0.02 & $<\mathrm{LD}$ & $<L D$ \\
\hline $\mathrm{Nd}$ & $\mu \mathrm{g} \mathrm{g}^{-1}$ & 0.03 & 0.16 & 0.08 & 0.02 & 0.02 \\
\hline $\mathrm{Ni}$ & $\mu \mathrm{g} \mathrm{g}^{-1}$ & 0.44 & 0.71 & 0.73 & 1.82 & 1.87 \\
\hline $\mathrm{Pb}$ & $\mu \mathrm{g} \mathrm{g}^{-1}$ & 0.18 & 0.17 & 1.59 & 0.19 & 0.11 \\
\hline $\mathrm{Pr}$ & $\mu \mathrm{g} \mathrm{g}^{-1}$ & 0.01 & 0.05 & 0.02 & 0.01 & 0.01 \\
\hline $\mathrm{Rb}$ & $\mu \mathrm{g} \mathrm{g}^{-1}$ & 0.95 & 3.15 & 0.40 & 0.38 & 0.33 \\
\hline $\mathrm{Sb}$ & $\mu \mathrm{g} \mathrm{g}^{-1}$ & 0.002 & 0.002 & 0.012 & 0.003 & 0.004 \\
\hline Sc & $\mu \mathrm{g} \mathrm{g}^{-1}$ & $<\mathrm{LD}$ & $<L D$ & $<\mathrm{LD}$ & $<\mathrm{LD}$ & $<\mathrm{LD}$ \\
\hline Sm & $\mu \mathrm{g} \mathrm{g}^{-1}$ & 0.006 & 0.02 & 0.02 & 0.004 & 0.003 \\
\hline Sn & $\mu \mathrm{g} \mathrm{g}^{-1}$ & $<\mathrm{LD}$ & $<\mathrm{LD}$ & $<\mathrm{LD}$ & $<\mathrm{LD}$ & $<\mathrm{LD}$ \\
\hline $\mathrm{Sr}$ & $\mu \mathrm{g} \mathrm{g}^{-1}$ & 1.43 & 1.50 & 1.34 & 0.26 & 0.26 \\
\hline $\mathrm{Ta}$ & $\mu \mathrm{g} \mathrm{g}^{-1}$ & $<\mathrm{LD}$ & $<\mathrm{LD}$ & $<\mathrm{LD}$ & $<\mathrm{LD}$ & 0.02 \\
\hline $\mathrm{Tb}$ & $\mu \mathrm{g} \mathrm{g}^{-1}$ & 0.001 & 0.002 & 0.002 & $<L D$ & $<\mathrm{LD}$ \\
\hline Te & $\mu \mathrm{g} \mathrm{g}^{-1}$ & $<\mathrm{LD}$ & $<\mathrm{LD}$ & 0.001 & $<L D$ & $<\mathrm{LD}$ \\
\hline Th & $\mu \mathrm{g} \mathrm{g}^{-1}$ & 0.02 & 0.04 & 0.05 & $<\mathrm{LD}$ & $<\mathrm{LD}$ \\
\hline $\mathrm{Ti}$ & $\mu \mathrm{g} \mathrm{g}^{-1}$ & 6.60 & 7.38 & 3.05 & 23.3 & 24.2 \\
\hline $\mathrm{TI}$ & $\mu \mathrm{g} \mathrm{g}^{-1}$ & 0.006 & 0.017 & 0.002 & 0.002 & 0.001 \\
\hline $\mathrm{Tm}$ & $\mu \mathrm{g} \mathrm{g}^{-1}$ & 0.001 & $<\mathrm{LD}$ & 0.001 & $<\mathrm{LD}$ & $<\mathrm{LD}$ \\
\hline U & $\mu \mathrm{g} \mathrm{g}^{-1}$ & 0.007 & 0.010 & 0.02 & 0.007 & 0.008 \\
\hline V & $\mu \mathrm{g} \mathrm{g}^{-1}$ & 0.13 & 0.20 & 0.05 & 0.02 & 0.02 \\
\hline W & $\mu \mathrm{g} \mathrm{g}^{-1}$ & $<\mathrm{LD}$ & 0.002 & $<\mathrm{LD}$ & $<\mathrm{LD}$ & 0.002 \\
\hline$Y$ & $\mu \mathrm{g} \mathrm{g}^{-1}$ & 0.05 & 0.04 & 0.06 & 0.11 & 0.11 \\
\hline
\end{tabular}


Table 3 (continued)

\begin{tabular}{|c|c|c|c|c|c|c|}
\hline & & \multicolumn{3}{|c|}{ Milky quartz } & \multicolumn{2}{|c|}{ Translucent quartz } \\
\hline & & ESIG15 & ESIG18 & ESIG19 & ESIG21a & ESIG21b \\
\hline $\mathrm{Yb}$ & $\mu \mathrm{g} \mathrm{g}^{-1}$ & 0.004 & 0.003 & 0.004 & $<\mathrm{LD}$ & 0.001 \\
\hline $\mathrm{Zn}$ & $\mu \mathrm{g} \mathrm{g}^{-1}$ & 0.23 & 0.15 & 0.25 & 0.17 & 0.32 \\
\hline $\mathrm{Zr}$ & $\mu \mathrm{g} \mathrm{g}^{-1}$ & 0.18 & 0.33 & 0.28 & 1.61 & 1.61 \\
\hline
\end{tabular}

photograph. HPQ material forms very few or no bubbles during this test.

Three samples of milky quartz and two samples of translucent quartz were selected for silica fused analysis. The size and the average content of bubbles present vary among the samples: 1) Milky quartz samples (ESIG15, ESI18 and ESIG19) are from the brecciated quartz vein. The rock is brittle, and clasts are cemented by smaller quartz crystals. These small quartz crystals (10 to $80 \mu \mathrm{m}$ in size) are separated upon grinding. Bubble characterization of all the milky quartz samples displays large quantity of bubble formation in fused grains (the green lines encircle the grains that have been effectively fused, where one or more bubbles are shown inside) and bubble size distribution in the range of $10-240 \mu \mathrm{m}$ with a mean diameter of $75 \mu \mathrm{m}$ (Fig. 7a, b, blue arrow). However, the majority (80\%) of bubbles are from 50 to $80 \mu \mathrm{m}$ in diameter while about $90 \%$ were smaller than $140 \mu \mathrm{m}$. Large clusters of small bubbles (less than $30 \mu \mathrm{m}$ ) were commonly observed in several fused grains of milky quartz (Fig. 7b, c, black arrow), and no bubble-free fused grains were observed in this quartz. 2) In translucent quartz, Fig. 7d permits to observe grains before and after fusion. In the fused state, the exact bubbles that form from each grain are distinctively observed. Translucent quartz samples do not produce many bubbles compared to the milky quartz, and also the size of each bubble is drastically reduced. More than $90 \%$ of the bubbles are less than $10 \mu \mathrm{m}$ (Fig. $7 \mathrm{~d}$ black arrow). Clean grains that have not produced bubbles upon fusion are also identified (Fig. 7d, green arrows) and represent about $40 \%$ of volume.

\section{Discussion}

\subsection{Geochemistry and fluid inclusions}

A number of factors likely played a role in the chemistry of trace elements in quartz studied in Etam. These are factors such as metamorphism and hydrothermal fluid action. Trace elements concentrations are chiefly regulated by the crystallization temperature $[6,57]$, the extent of melt fractionation in igneous and pegmatitic quartz [58-60] and the chemistry and acidity of the fluid from which the quartz crystallized in diagenetic and hydrothermal quartz [61-63].

Monecke et al. [64], Baron et al. [65] define Li, Al, K, $\mathrm{Rb}, \mathrm{Sr}$, and $\mathrm{Y}$ concentration in quartz as tools that allow distinguishing quartz from metamorphic processes from quartz of hydrothermal origin. Korneliussen et al. [66], Müller et al. [67] show that, despite variations, the previous elements have generally lower concentration in metamorphic quartz compared to hydrothermal quartz. According to [58], the $\mathrm{Ge} / \mathrm{Ti}, \mathrm{Ge} / \mathrm{Be}, \mathrm{P} / \mathrm{Ge}$ and $\mathrm{P} / \mathrm{Be}$ ratios of quartz are strongly sensitive to the origin and evolution of the granitic melts. The Ge/Ti ratio therefore is the most suitable for analyzing and understanding petrogenetic processes in granitic igneous rocks. Research work discriminating sources of quartz deposit have been carried out previously worldwide and abundant literature is available $[3,6,11$, $45,52,67,68]$. Trace elements in quartz are then generally used as tools for differentiating pegmatite, igneous, hydrothermal and metamorphic quartz. These studies are used for benchmarking procedures and comparing results of this study.

From the ICP-MS or LA-ICP-MS analysis, Etam quartz samples show more or less variation between milky and translucent quartz trace elements concentration. Figure 8 a shows similar trend variation in trace elements concentration for both quartz and suggests the similar processes of formation of Etam quartz. Data available $[14,69,70]$ show that $\mathrm{Al}^{3+}, \mathrm{Ti}^{3+}$ and $\mathrm{Ge}^{3+}$ commonly substitute $\mathrm{Si}^{4+}$ in quartz structure and the charge defect created by these substitutions is compensated by monovalent ions $\mathrm{Li}^{+}, \mathrm{Na}^{+}$, $\mathrm{K}^{+}$and $\mathrm{H}^{+}$.

The $\mathrm{Al} / \mathrm{Li}$ ratio is often used to constrain crystallization conditions of quartz $[52,65,72]$. This ratio varied from 67.55 to 153.47 in milky quartz and is 209.8 in translucent quartz samples. Thus, the Al/Li value in Etam quartz is far from the $\mathrm{Al} / \mathrm{Li}$ ratio in pegmatitic quartz, often $<10[45,52]$ and also far from hydrothermal quartz studied elsewhere $[11,64]$. Monecke et al. [64] distinguished metamorphic quartz from hydrothermal quartz by low content of $\mathrm{Li}, \mathrm{Al}$, $\mathrm{K}, \mathrm{Rb}, \mathrm{Sr}$ and $\mathrm{Y}$ in recrystallized metamorphic quartz. Lithium, Rb, Sr and $\mathrm{Y}$ show low concentrations in Etam quartz, similar to most of the metamorphic quartz described in the literature $[64,73,74]$. Aluminum and $\mathrm{K}$ concentrations are high and comparable to some pegmatite quartz studied in the world [52], except for sample E-SIG 19 which shows K 


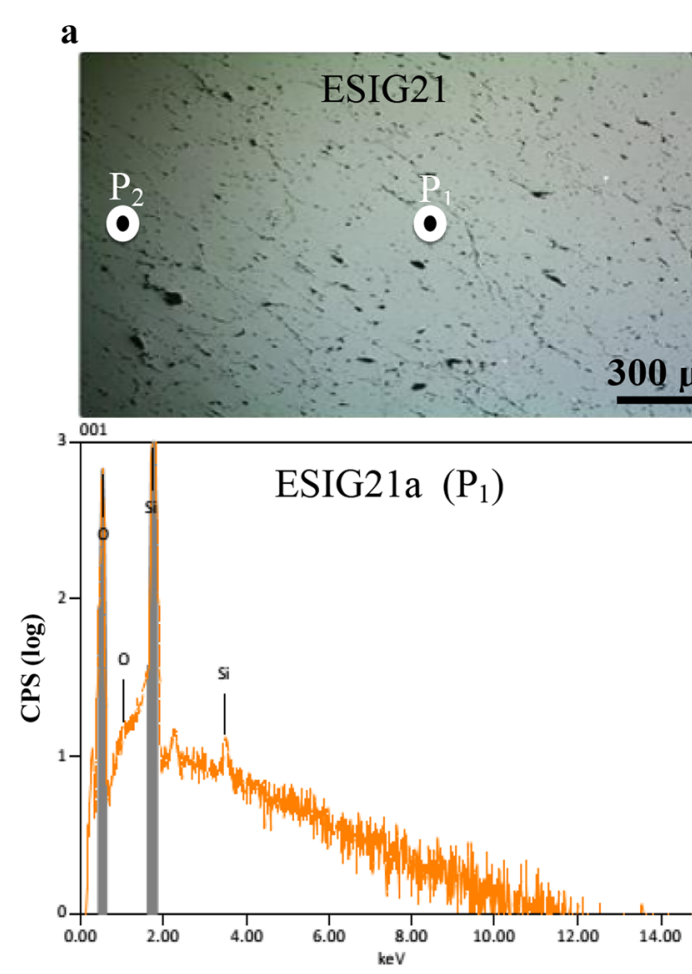

b
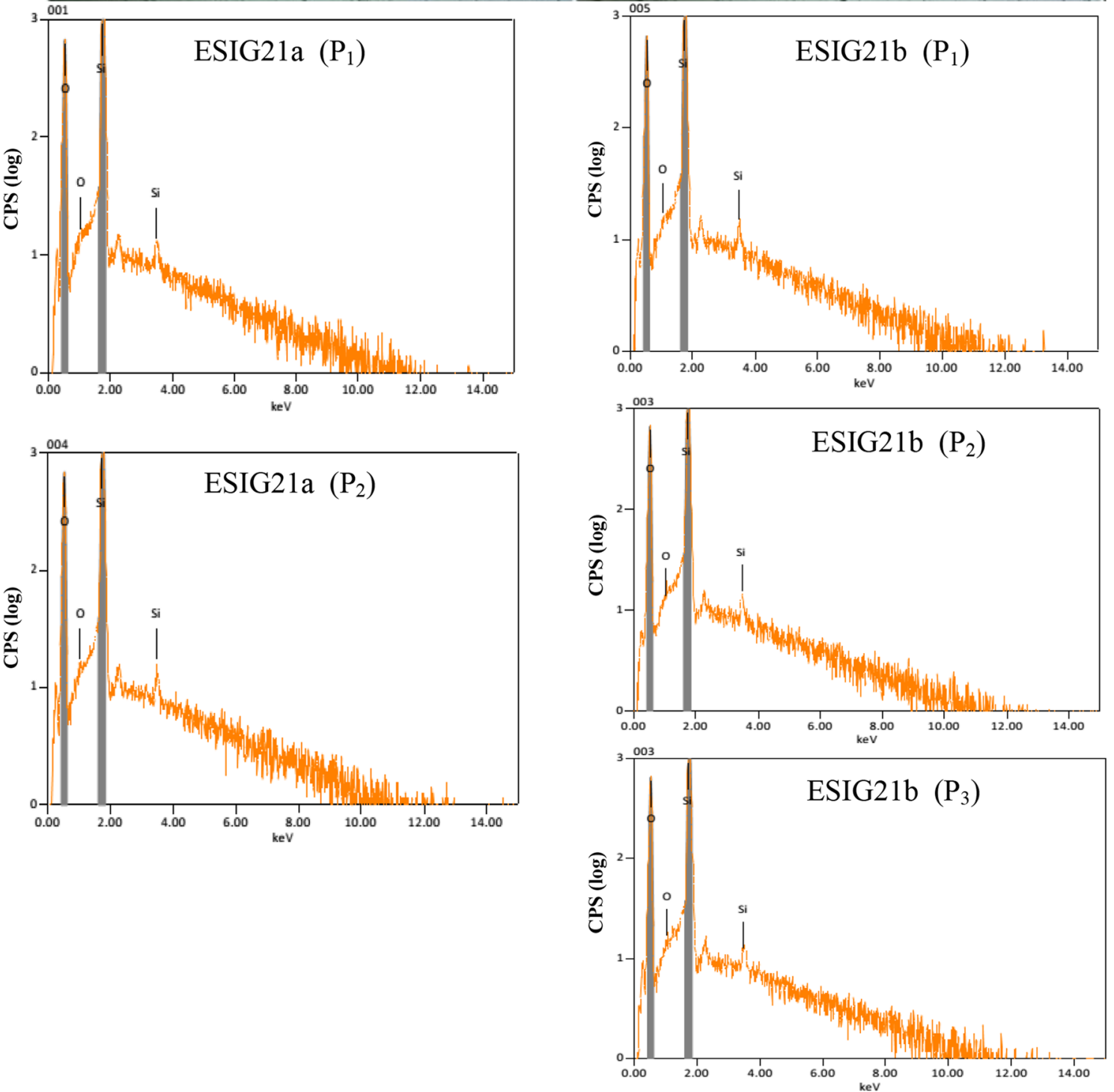

Fig. 3 SEM-EDS images and patterns for translucent quartz: a image for sample ESIG21a and EDS patterns at point $1\left(P_{1}\right)$ and $2\left(P_{2}\right), \mathbf{b}$ image for sample ESIG21b and EDS patterns at points $1\left(P_{1}\right), 2\left(P_{2}\right)$ and $3\left(P_{3}\right)$

below detection limit. Daughter crystals in fluid inclusions in this quartz are mostly salts, and therefore, Al is probably incorporated in the quartz structure added by hydrothermal fluid circulating during metamorphic events. Indeed, milky quartz in Etam was probably (re)crystallized under greenschist to amphibolitic metamorphic condition [44] in the shear zone. The relative low concentration of $\mathrm{Na}$ and $\mathrm{K}$ coupled with the low $\mathrm{Al} / \mathrm{Li}$ ratio suggests that the charge balances are compensated mainly by $\mathrm{H}^{+}$[75] from hydrothermal fluid in milky and translucent quartz, since either 


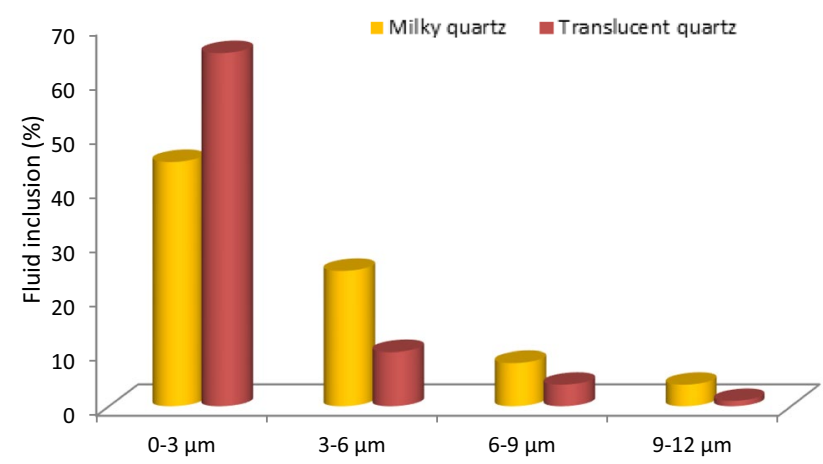

Fig. 4 Histogram showing proportion of fluid inclusions in milky and translucent quartz in Etam a metamorphic event or the brittle nature of the rock has enhanced fluid flow in the area.

The $\mathrm{Ge} / \mathrm{Fe}$ ratio (mean $=0.0027$ ) is very low in milky quartz compared to translucent quartz (mean $=0.031$ ) and to hydrothermal quartz studied in Olhos D'agua (Ge/ $\mathrm{Fe}=0.15)$ and Corinto $(\mathrm{Ge} / \mathrm{Fe}=0.3$ [45]. It is also much smaller compared to pegmatitic quartz which presents $\mathrm{Ge} / \mathrm{Fe}$ ratio ranges from 4.5 to $0.1[52,76]$. According to [76], this low Ge/Fe ratio suggests the early crystallization stage of quartz probably during metamorphic event and containing high concentration of Fe. Furthermore, the rare-earth elements (REE) distribution pattern of this quartz type shows the characteristics of typical metamorphic quartz samples $[64,74]$ with an enrichment of LREE (Fig. 8b). The samples contain very low to negligible HREE when compared to standard HPQ values $[6,51]$, and thus
Fig. 5 Photomicrographs of fluid inclusions in milky quartz samples: a large in quantities and small in size fluid inclusions in milky quartz, b dipyramidal monophasic inclusions probably apatite (orange arrow), c Irregular (black arrow) and regular (blue arrow) two-phase inclusions, $\mathbf{d}$ negative quartz crystals (black arrow) and cubic inclusion (red arrow), e mineral inclusion (red arrow) and melt inclusion (green arrow), f fluid inclusion surrounded by small inclusion (satellite inclusions)
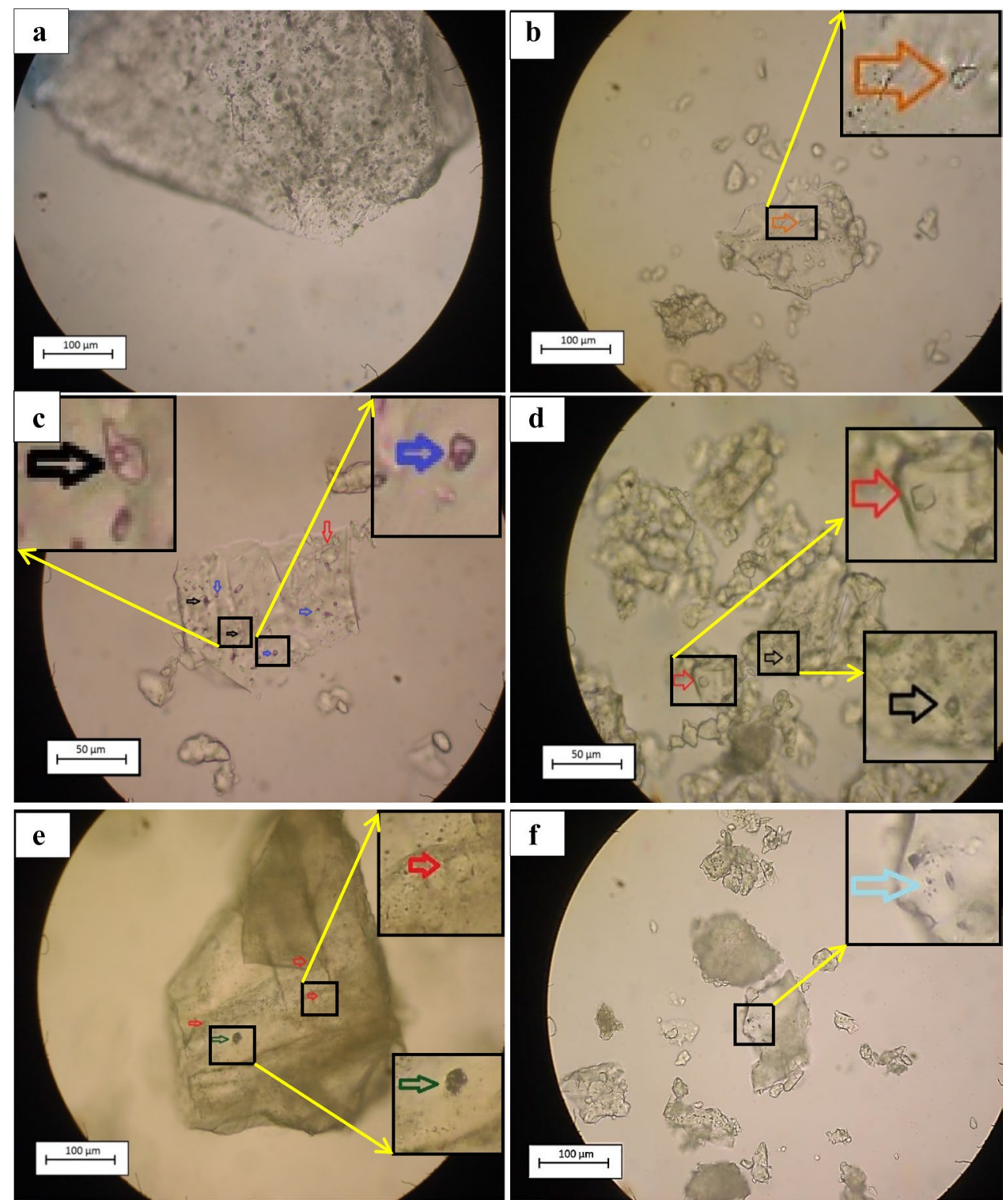

SN Applied Sciences A SPRINGER NATURE journa 
Fig. 6 Photomicrographs of fluid inclusions in translucent quartz: a Negative biphasic crystal inclusions generally oriented, b dipyramidal monophasic fluid inclusion (orange arrow) and mineral inclusion (pink arrow), c needle mineral inclusion, probably rutile (gray arrows)
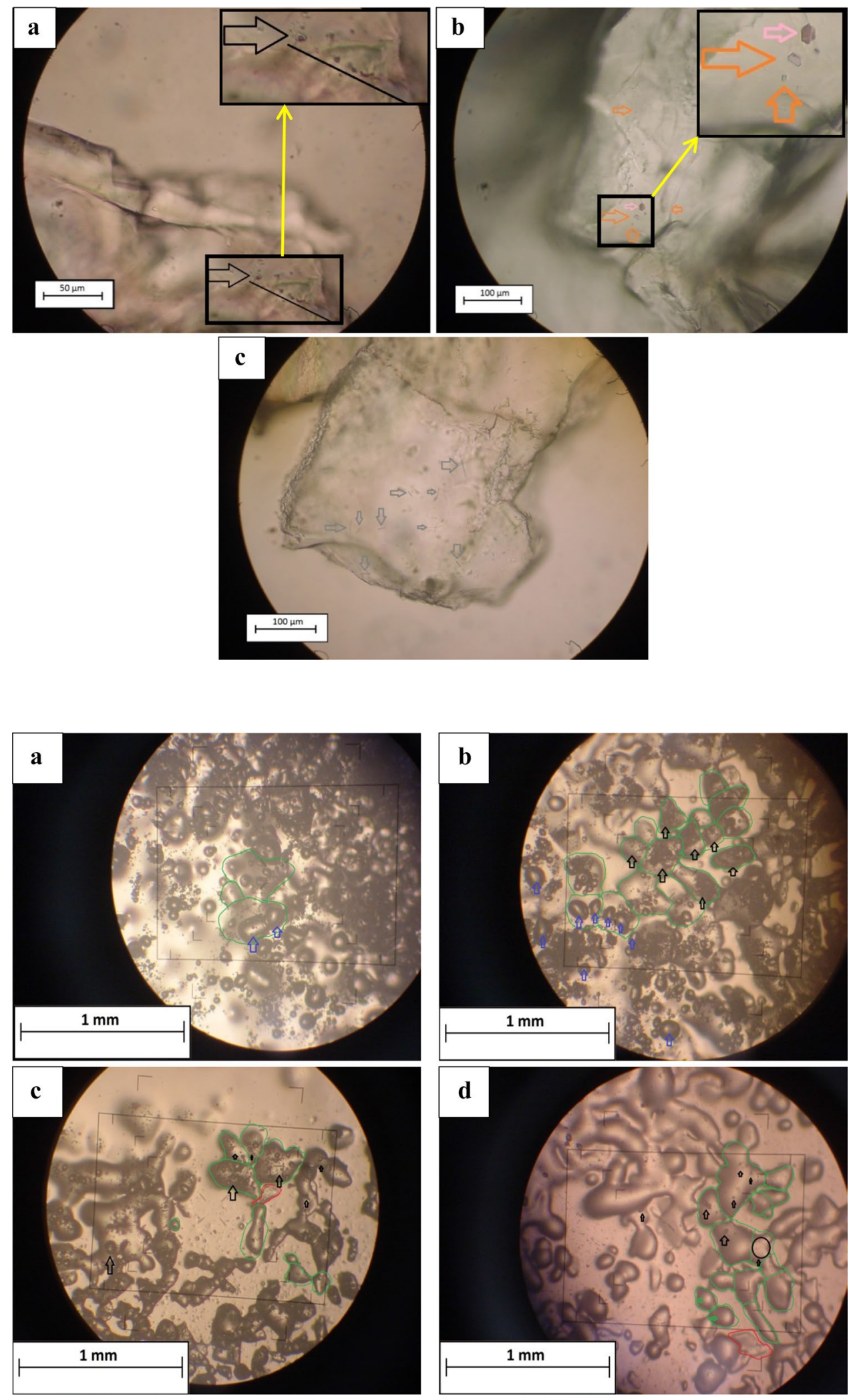

Fig. 7 Photomicrographs of the fused quartz powders over silica plates where fused grains can be observed with formed bubbles inside. a High quantity and very large bubble (blue arrow) formation in fused grains in milky quartz, b, c large quantity of bubble and clusters of small bubbles (black arrow) milky quartz, d cleaned fused grain with free bubble formation (green arrow) and small bubbles in grains (black arrow) in translucent quartz. The green lines circle the grains that have been effectively fused; the red lines circle the "unfused" grains their chondrite-normalized REE patterns cannot be shown on spider diagram. The absence of a positive Ce anomaly is suggested to reflect the igneous protolith of this quartz.
This corroborates $[43,44]$ who suggested that the protolith of the fault rocks is probably igneous rocks in Etam.

\section{SN Applied Sciences}




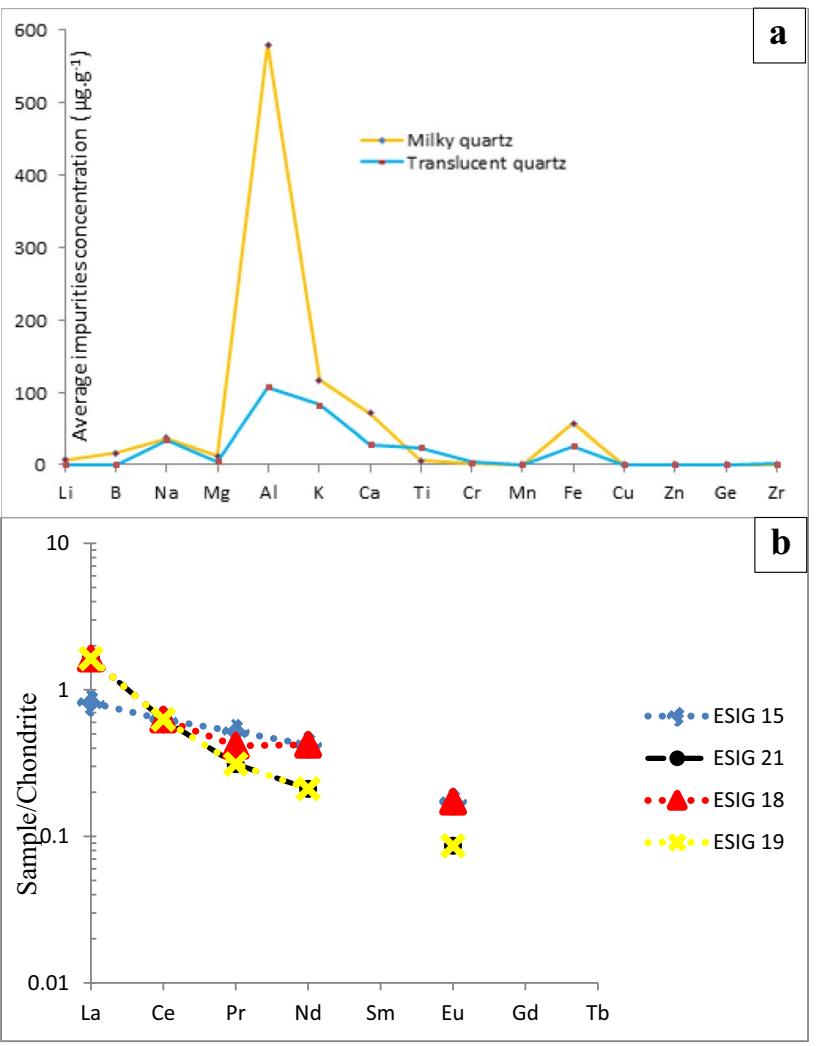

Fig. 8 Trace elements and REE variation in Etam quartz: a some trace element concentration average in Etam quartz, milky and translucent quartz patterns display similar trends with translucent quartz showing low concentration in all elements, except for Ti, b chondrite-normalized rare-earth element (REE) distribution patterns of Etam quartz (normalization according to data of Anders and Grevesse [71])

Fluid inclusions in milky quartz display features related to recrystallization under metamorphic conditions as shown by the higher volume of two-phase fluid inclusion with irregular shapes containing brine and $\mathrm{CO}_{2}$ [77] and the alignment of the inclusions to define trails. However, the abundance and the variability of fluid inclusions suggest that this quartz benefitted from hydrothermal fluids inputs. Impurities contained in it are similar to some hydrothermal quartz data available $[16,64]$. Therefore, it is suggested that quartz in Etam was probably formed during metamorphic processes implying circulation of hydrothermal fluid saturated in silica [73], followed by silica precipitation and formation of hydrothermal veins. Some data available [45] reveal that hydrothermally formed quartz of Pan-African age was submitted to some degree of metamorphism. These conditions are similar to the geological context at Etam environment. Furthermore, the Etam area and Santa Helena (Olhos D'_agua and Corinto) in Brazil are situated in N070E-oriented thrust zone (Fig. 1a) and were probably subjected to the same metamorphic degree during Pan-African event. Along shear zones, crystal-plastic deformation is an important process in the purification of quartz. Quartz has the capacity to response to stress along ductile shear zones in a combined brittle-ductile manner. Ductile failure results in quartz ribbons, deformation lamellae and undulose extinction and fracture-controlled slip. These features are observed in the pure quartz grains in the Etam shear zone.

\subsection{Trace elements incorporation into quartz}

The Al concentration in the Etam quartz samples varies (107 to $811 \mu^{g_{~ g}}{ }^{-1}$, Table 3). Rusk et al. [61], Götze et al. [78], Rusk et al. [79] demonstrated that high concentration of $\mathrm{Ti}$ and corresponding low concentration of $\mathrm{Al}$ are closely related to high temperature in hydrothermal quartz. The concentration of $\mathrm{Ti}$ in quartz reflects the temperature of recrystallization during metamorphism $[48,49,57,58,67$, 80]. Titanium concentration in milky quartz is similar to that of hydrothermal quartz described in the literature. The microscope studies of the Etam quartz did not show rutile as inclusions in milky quartz. Therefore, the Ti concentration in this quartz samples is presumably incorporated in the structure of the quartz and the hydrothermal fluids seem not to have played a major role in its genesis or the fluid was Ti poor. In the translucent quartz samples, the high content of Ti compared to the milky quartz is possibly related to mineral inclusions as needles that seem to be rutile inclusions were abundantly observed under the microscope study. The absence of Ti-Fe-rich mineral (e.g., ilmenite) in this geological environment suggests that $\mathrm{Ti}$ was probably added by Ti-rich hydrothermal fluids from other environment.

The high Al concentration in Etam quartz was probably induced during hydrothermal fluid-assisted metamorphism at elevated temperature $[45,64]$. Such phase transformations are widespread in the area [40,44]. Iron concentration is abnormally high in the translucent quartz compared to that of $\mathrm{HPQ}[6,51]$. Also [6] stated that quartz crystals in contact with Fe-rich minerals show high concentration of Fe. Thus, the Fe concentrations in quartz are predominantly diffusion-controlled. Indeed, clusters of small quartz grains containing red spots, probably iron oxide, were observed in the fluid and mineral inclusion study. The origin of these spots is not known, but probably hydrothermal fluids circulating in the area were Fe-rich.

The high concentration in quartz of $\mathrm{Ca}, \mathrm{K}, \mathrm{Mg}$ and $\mathrm{Na}$ is sometimes due to saline environment. But generally these elements are carried in quartz by fluids inclusions or mineral inclusions [11, 73]. Indeed, the microscope observation shows several $\mathrm{NaCl}$ crystal inclusions in Etam quartz that probably carried some of these elements. 
Fig. 9 Photomicrographs of the fused quartz powders over silica plates. a Translucent quartz from Etam, b milky quartz from Olhos D'agua, c transparent quartz from Corinto, d lota commercial powder [11]. Small black dots represent bubbles

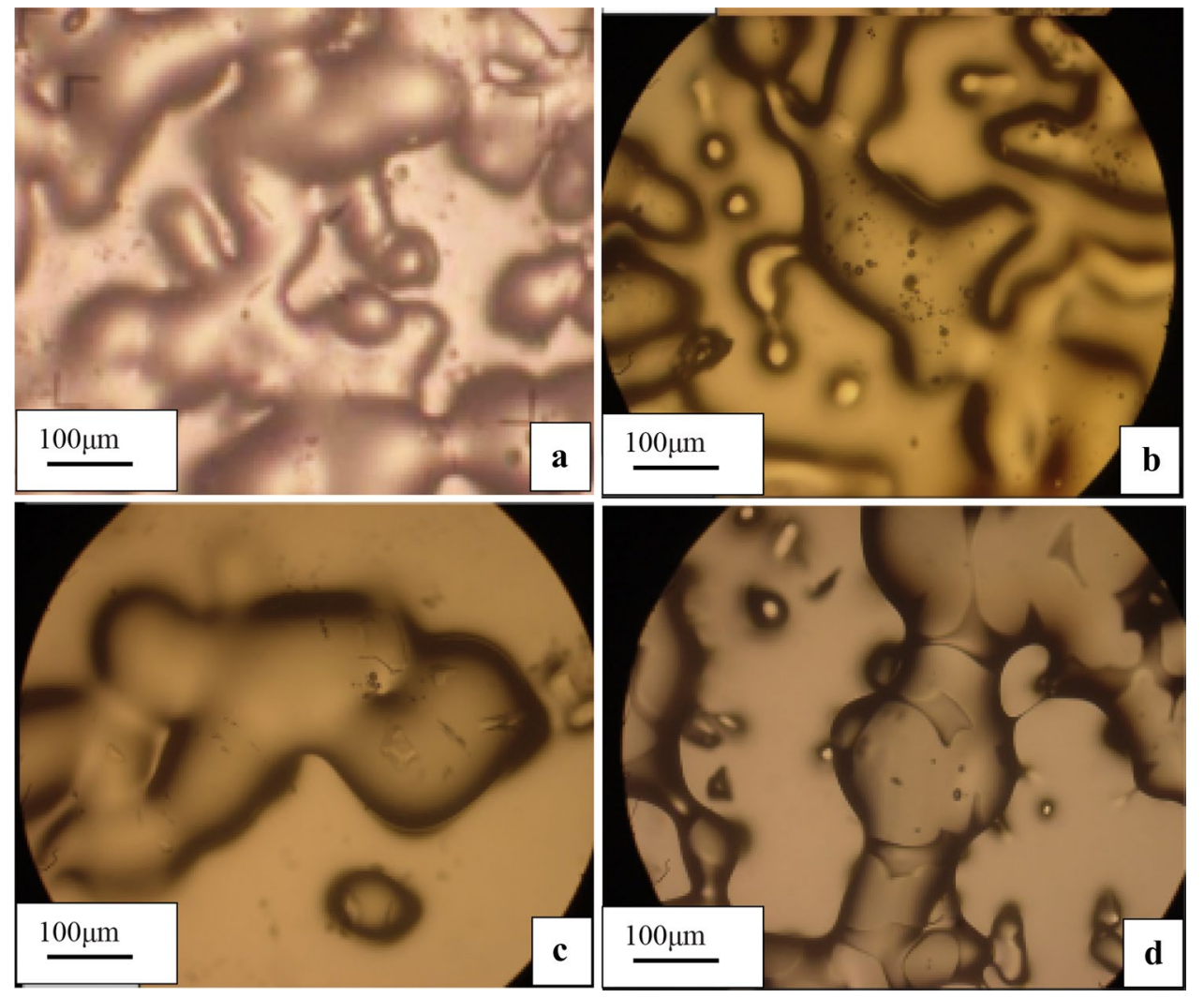

\subsection{Technological aspect}

Quartz in this study has mainly two-phase fluid inclusions containing saline water and $\mathrm{CO}_{2}$. The behavior of quartz upon fusion has been described by several authors [10-12, 45]. The amount of gas liberated during fusion is related to the size and density of fluid inclusions. At Etam, the translucent quartz yielded better fusion test results compared to the milky quartz variety. The results of the bubble formation test for the Etam translucent quartz (Fig. 9a) are compared here to the milky samples (Fig. 9b) and the transparent quartz (Fig. 9c) from Corinto and Olhos D'agua, respectively (samples from the Serra de Santa Helena formation-Brazil) [45], and to the commercial powder, IOTA powder (Fig. 9d).

The comparison shows that the milky quartz samples from Olhos D'agua formed more bubbles compared to the three other samples. Moreover, samples from Etam translucent quartz, transparent quartz or the IOTA powder have formed small bubbles compared to the milky quartz samples during fusion over silica plate. Between sample of translucent quartz from Etam, transparent quartz from Olhos D'agua or the IOTA powder, the variation in terms of bubble size and bubble volume is negligible. These samples therefore seem similar from the point of view of bubbles formation after fusion over silica plate. Furthermore, the translucent quartz sample from Etam has few bubbles formed, similar to the transparent quartz from Olhos D' agua, which was concluded to be equivalent to commercial IOTA powder [11].

The inclusions in both quartz varieties are different in size, in quantity and types. This observation suggests that either the two quartz varieties were subjected to different geological events (hydrothermal action or metamorphism) that could modify fluid inclusion features in it or inclusions were initially formed differently due to different processes [45]. Furthermore, high-stress tectonic geological environment can induce fluid inclusion deformation due to fluid loss [56, 81-85]. Milky quartz in Etam developed along a brittle-ductile shear zone [44] and shows large inclusions observed surrounded by small inclusions or satellite inclusions. This can be supported by $[86]$ and $[55,56]$ who showed that due to deviatoric stress, inclusions can be deformed and dismembered, giving a large relic inclusion and a cluster of small neonate (satellite) inclusions around them.

The chemical analysis in Table 3 shows impurities in some Etam quartz samples. The translucent quartz variety has more promising results for industrial applications, compared to the milky quartz. According to [45], impurities in fluid inclusions are less hard to eliminate than the incorporated ones in quartz structure. Therefore, the

\section{SN Applied Sciences}


most principal elements with high concentrations in the translucent quartz are: $\mathrm{Al}$ (means $107 \mathrm{\mu g} \mathrm{g}^{-1}$ ), $\mathrm{K}$ (means $82.4 \mathrm{\mu g} \mathrm{g}^{-1}$ ), Fe (means $26.01 \mu \mathrm{g} \mathrm{g}^{-1}$ ). According to [11], removing $\mathrm{Al}$ impurities from quartz by using HF or concentrated acid mixtures is costly and constitutes environmental hazards. Therefore, for quartz to be suitable as HPQ raw material, it should meet certain natural requirements, or the processing should be done by methods that are less hazardous and more efficient. Indeed, an efficient fluorine-free leaching system to purify quartz has been developed with an objective to establish a fluoride-free technology for improving quartz quality [16]. According to the authors, the method can consistently purify quartz by removing elements impurities up to $88.2 \mathrm{wt} \%, 99.0 \mathrm{wt} \%$ and $98.1 \mathrm{wt} \%$, for the $\mathrm{HCl}-\mathrm{NH} 4 \mathrm{Cl}$ system, and $87.5 \mathrm{wt} \%$, $98.1 \mathrm{wt} \%$ and $98.2 \mathrm{wt} \%$ for the $\mathrm{H}_{2} \mathrm{SO}_{4}-\mathrm{NH}_{4} \mathrm{Cl}$ system, respectively, for $\mathrm{Al}, \mathrm{K}$ and Fe.

Based on chemical studies coupled with bubble formation characteristics in Etam quartz, the milky quartz can necessitate important and costly purification process to meet HPQ standard. The deposit therefore due to the high $\mathrm{SiO}_{2}$ content (up to $99.75 \mathrm{wt} \%$ ) can be used as raw materials for the refractory industry with a production of silica stone, silicon and silicon alloys [51]. Translucent quartz in the other hand shows optimistic results as quartz raw material that can be used in some quartz applications industries without necessarily purification processes. It can produce, for instance, silica glass which is common raw material largely used in optical and telecommunication industries.

\subsection{Economic appraisal}

According to the definition of $\mathrm{HPQ}$, the milky quartz from Etam does not meet the requirement of a high-purity quartz deposit. The sum of the concentration of unwanted elements in this quartz type is $\geq 500 \mathrm{\mu g} \mathrm{g}^{-1}$. The translucent quartz variety is fine-grained, translucent and massive. These aspects are often an indication of good fusion behavior [10]. Regarding only the fusion behavior, this quartz type can be used to produce transparent glass. The problematic feature is the chemical purity. With the exception of $\mathrm{Li}\left(0.5 \mu \mathrm{g} \mathrm{g}^{-1}\right)$ and $\mathrm{B}$ (below detection limit), all the trace elements which determine the purity of quartz as per $\mathrm{HPQ}$ definition are above the required limits (Table 3 ). The $\mathrm{Ti}$ and $\mathrm{Fe}$ are especially high. These impurities are probably located in the mineral inclusions which can easily be eliminated if proper processing tests are conducted. Translucent quartz show similar characteristics to some samples from the Santa Helena quartz deposit [45] as shown by the fusion over silica plate and bubble formation. Therefore, further investigations for such quartz type in the Etam area are advised. Several veins as translucent quartz vein with similar orientation exist in the area. These veins crop mostly in metamorphic basement and are easily accessible. The volume of the milky and translucent quartz resource that defines the distinct Etam ridge above the surrounding peneplain is estimated at $\sim 6 \mathrm{~km}^{3}$ pointing to an exploitable deposit considering that drilling will only add to the subsurface volume.

\section{Conclusion}

The investigation of Etam quartz samples in the southwest region (Cameroon) by the combination of ICP-MS, LA-ICPMS, SEM-EDS resolved trace-element analysis and characterized in detail the type, the abundance of trace elements in quartz and the reconstruction of processes responsible for their formation and the amount of trace-element concentrations. The analyses show that the $\mathrm{SiO}_{2}$ content is very high (98.46-99.75 wt\%) with very low concentration of trace elements. The process of formation of both deposit types is suggested to be similar: The translucent quartz is clearly older than the milky quartz although both probably formed under metamorphic conditions and benefited from a contribution of hydrothermal fluids.

The translucent quartz of Etam shows optimistic results as ore resource after analysis. Principal impurities in it are $\mathrm{Al}\left(\right.$ mean $\left.107 \mu \mathrm{g} \mathrm{g}^{-1}\right)$, Ca (mean $27.85 \mu \mathrm{g} \mathrm{g}^{-1}$ ) Fe (mean $26.05 \mu \mathrm{g} \mathrm{g}^{-1}$ ) and $\mathrm{Ti}$ (mean $23.75 \mu \mathrm{g} \mathrm{g}^{-1}$ ). According to the HPQ definition, quartz from Etam does not meet the requirement of a high-purity quartz deposit. Chemically and technologically, the translucent quartz is mediumpurity quartz with good fusion behavior producing very little number of bubbles; thus, it could be used to produce transparent glass. Moreover, the main impurities in translucent quartz are mostly in fluid and mineral inclusions; thus, the purification using efficient method can purify this quartz and produce quartz crucibles with high-purity qualities widely used in industries.

Acknowledgements This paper is part of ongoing Ph.D. thesis by the first author. This work has been financially supported by the Ministry of Higher Education, Cameroon, through the Special Allocation for the Modernization of Research (SAMR) granted to the first author. Authors thank the Conselho Nacional de Desenvolvimento Cientifico e Tecnologico (CNPq) for the financial support. We highly appreciate the support of Prof. Nzenti Jean Paul who suggested constructive revisions to the various versions of the manuscript. The incisive comments of two anonymous reviewers and the Editor are much appreciated.

Authors' contributions CES, CS and MA were involved in study conception and design. CES, CS and MJLN were involved in acquisition of data. CES, CKS, CS, EF and MFMS contributed to analysis and interpretation. CS drafted the manuscript. CES, CKS, EF and MFMS were involved in critical revision of the manuscript. All authors read and approved the final manuscript. 
Funding This study received financial support from the Ministry of Higher Education, Cameroon, through the Special Allocation for the Modernization of Research (SAMR) granted to CS and CES. MFMS, $\mathrm{EF}$ and $\mathrm{CKS}$ received financial support from Conselho Nacional de Desenvolvimento Cientifico e Tecnologico (CNPq).

\section{Compliance with ethical standards}

Conflict of interest The authors declare that they have no conflict of interest.

\section{References}

1. Haus R, Prinz S, Priess C (2012) Assessment of high purity quartz resources. In: Götze J, Möckel R (eds) Quartz: deposits, mineralogy and analytics. Springer, Berlin, pp 29-51

2. Moore $P(2005)$ High purity quartz. Ind Miner 455:53-57

3. Haus R (2005) High demands on high purity. Ind Miner 10:62-67

4. Barkhudarov EM, Christofi N, Kossyi IA, Misakyan MA, Sharp J, Taktakishvili IM (2008) Killing bacteria present on surfaces in films or in droplets using microwave UV lamps. World J Microl Biotechnol 24:761-769

5. Wait IW, Johnston CT, Blatchley ER (2007) The influence of oxidation reduction potential and water treatment process on quartz lamp sleeves fouling in ultraviolet disinfection reactors. Water Res 41:2427-2436

6. Muller A, Wanvik JE, Ihlen PM (2012) Petrological and chemical characterisation of High-Purity Quartz deposits with examples from Norway. In: Gotze J, Mockel R (eds) Quartz: deposits, mineralogy and analytics. Springer, Heidelberg, pp 71-118 Natural hydrothermal quartz. Mineral Mag 73:615-632

7. Minami T, Maeda S, Higasa M, Kashima K (2011) In-situ observation of bubble formation at silicon melt-silica glass interface. J Cryst Growth 318:196-199

8. Yahamara K, Huang X, Sakai S, Utsonomiya A, Tsurita Y, Hoshikawa K (2001) Surface of silica glass reacting with silicon melt: effect of raw materials for silica crucibles. Jpn J Appl Phys 40:1178-1182

9. Huang X, Kishi H, Oishi S, Watanabe H, Sanpei K, Sakai S, Hoshikawa K (1999) Expansion behavior of bubbles in silica glass concerning Czochralski (CZ) Si growth. Jpn J Appl Phys 38:353-355

10. Santos MFM, Fujiwara E, De Paula FD, Suzuki CK (2013) Opacity measurements on quartz and its influence on silica glass properties. Int J Miner Process 124:141-144

11. Santos MFM, Fujiwara E, Schenkel EA, Enzweiler J, Suzuki CK (2015) Quartz sand resources in the Santa Maria Eterna formation, Bahia, Brazil: a geochemical and morphological study. J S Am Earth Sci 62:176-185

12. Griscom DL (2006) Self-trapped holes in pure silica glass: a history of their discovery and characterization and an example of their critical significance to industry. J. Non Cryst Solids 3512:2601-2617

13. Suzuki CK, Santos MFM, Ono E, Fujiwara E (2012) Strategic high quality quartz supply for fusion into silica glass. In: Varshneya AK, Schaeffer HA, Richardson KA, Wightman M, Pye D (eds) Processing properties and applications of glass and optical materials: ceramic transactions. The American Ceramic Society, Baltimore, pp 69-74

14. Götze J (2009) Chemistry, textures and physical properties of quartz-geological interpretation and technical application. Miner Mag 73:645-671
15. Yang C, Li S, Bai J, Han S (2018) Advanced purification of industrial quartz using calcination pretreatment combined with ultrasound-assisted leaching. Acta Geodyn Geomater 15:187-195. https://doi.org/10.13168/AGG.2018.0014

16. Lin M, Pei Z, Lei S (2017) Mineralogy and processing of hydrothermal vein quartz from Hengche, Hubei Province (China). Minerals 7:161. https://doi.org/10.3390/min7090161

17. Penaye J, Toteu SF, Van Schmus WR, Nzenti JP (1993) U-Pb and $\mathrm{Sm}-\mathrm{Nd}$ preliminary geochronologic data on the Yaoundé series, Cameroon: re-interpretation of the granulitic rocks as the suture of a collision in the "centrafrican" belt. C R Acad Sci Paris 317:789-794

18. Toteu SF, Van Schmus Penaye J, Michard A (2001) New U-Pb and $\mathrm{Sm}-\mathrm{Nd}$ data from North-Central Cameroon and its bearing on the pre-Pan-African history of Central Africa. Precambrian Res 108:45-73

19. Toteu SF, Penaye J, Poudjom Djomani YH (2004) Geodynamic evolution of the Pan African belt in Central Africa with special reference to Cameroon. Can J Earth Sci 41:73-85

20. Almeida FF, Hasui Y, Brito de Neves BB, Fuck RA (1981) Brazilian structural provinces. Earth Sci Rev 17:1-29

21. Castaing C, Feybesse JL, Thieblemont D, Triboulet C, Chevremont $P$ (1994) Paleogeographical reconstructions of the Pan-African/ Brasiliano orogen: closure of an oceanic domain or intracontinental convergence between major blocks. Precambrian Res 69:327-344

22. Neves SP, Vauchez A, Archanjo C (2006) Shear zone-controlled magma emplacement or magma-assisted nucleation of shear zones? Insights from northeast Brazil. Tectonophysics 262:349-364

23. Ngako V, Affaton P, Nnange JM, Njanko TH (2003) Pan-African tectonic evolution in central and Southern Cameroon: transpression and transtension during sinistral shear movements. J Afr Earth Sci 36:207-214

24. Ngako V, Affaton P, Njonfang E (2008) Pan-African tectonic in northwestern Cameroon: implication for history of western Gondwana. Gondwana Res 14:509-522

25. Njiekak G, Dörr W, Tchouankoue JP, Zulauf G (2008) U-Pb zircon and microfabric data of (meta) granitoids of western Cameroon: constraints on the timing of pluton emplacement and deformation in the Pan-African belt of Central Africa. Lithos 102:460-477

26. Penaye J (1988) Pétrologie et structure des ensembles métamorphiques au Sud-Est de Poli (Nord-Cameroun). Rôles respectifs du socle protérozoique inférieur et de l'accrétion et de l'accrétion crustale panafricaine. Thèse de I'INPL, Nancy

27. Tanko Njiosseu EL, Nzenti JP, Njanko T, Kapajika B, Nédelec A (2005) New U-Pb zircon ages from Tonga (Cameroon): coexisting Eburnean-Transamazonian (2.1 Ga) and Pan-African (0.6 Ga) imprints. C R Géosci 337:551-562

28. Ganwa A, Frisch W, Siebel W, Shang CK, Mvondo OJ, Satir M, Tchakounte NJ (2008) Zircon 207Pb-206Pb evaporation ages of Pan-African metasedimentary rocks in the Kombé-Il area (Bafia Group, Cameroon): constraints on protolith age and provenance. J Afr Earth Sci 51:77-88

29. Soba $D$ (1989) La série de Lom: étude géologique et géochronologique d'un bassin volcanosédimentaire de la chaîne panafricaine de l'Est du Cameroun. Thèse de Doctorat d'Etat, Université de Paris VI, France

30. Tchaptchet Tchato D, Schulz B, Nzenti JP (2009) Electron microprobe dating and thermobarometry of Neoproterozoic metamorphic events in the Kekem area, Central African Fold Belt of Cameroon. Neues Jahbür Minerol Abh 186:95-109

31. Bouyo Houkechang M, Toteu SF, Deloule E, Penaye J, Schumus Van (2009) U-Pb and Sm-Nd dating of high-pressure granulites from Tcholliré and Banyo regions: evidence for a pan African 
granulite facies metamorphism in north-central Cameroon. J Afr Earth Sci 54:144-154

32. Nzenti JP, Kapajika B, Wörner G, Lubala RT (2006) Synkinematic emplacement of granitoids in a Pan-African shear zone in Central Cameroon. J Afr Earth Sci 45:74-86

33. Tagne-Kamga G (2003) Petrogenesis of the Neoproterozoic Ngondo plutonic complex (Cameroon, West Central Africa): a case of late-collisional ferro-potassic magmatism. J Afr Earth Sci 36:149-171

34. Kouankap NGD, Nzenti JP, Suh CE, Ganno S (2010) Geochemistry of ferriferous, high-K calc-alkaline magmas from the BanefoMvoutsaha Massif (NE Bafoussam), Central Domain of the PanAfrican Fold Belt, Cameroon. Open Geol J 4:21-34

35. Mosoh BCK, Frimmel HE, Ze A, Suh CE (2012) Age and origin of Pan-African granites and associated U-Mo mineralization at Ekomedion, southwestern Cameroon. J Afr Earth Sci 88:15-37

36. Ngnotué T, Nzenti JP, Barbey P, Tchoua MF (2000) The NtuiBetamba high grade gneisse: a northward extension of the Pan-African Yaoundé Gneisses in Cameroon. J Afr Earth Sci 31:369-381

37. Asaah AV, Zoheirc B, Lehmann B, Frei D, Burgess R, Suh CE (2015) Geochemistry and geochronology of the $\sim 20$ Ma gold-associated Batouri granitoids, Cameroon. Int Geol Rev 57:1485-1509

38. Ntiéche B, Mohan MR, Moundi A, Mounjouohou MA (2016) Petrogenesis and geochemical characterization of the granitoids of the Magba shear zone west Cameroon central Africa. Open J Geol 6:812-839

39. Ntiéche B, Mohan MR, Moundi A (2017) Granitoids of the Magba shear zone, west Cameroon, Central Africa: evidence for emplacement under transpressive tectonic regime. J Geol Soc India 89:33-46

40. Njome MS, Suh CE (2005) Tectonic evolution of the Tombelgraben basement, southwestern Cameroon. Episodes 28:37-41

41. Kankeu B, Greiling RO, Nzenti JP (2009) Pan-African strike-slip tectonics in eastern Cameroon-Magnetic fabrics (AMS) and structure in the Lom basin and its gneissic basement. Precambrian Res 174:258-272

42. Njome MS, De Wit MJ (2014) The Cameroon line: analysis of an intraplate magmatic province transecting both oceanic and continental lithospheres: constraints, controversies and models. Earth-Sci Rev 139:168-194

43. Njome MS, Suh CE, Ghogomu RT (2003) A microstructural approach to interpreting the structural setting of the Tombel graben, south western Cameroon. GeoActa 2:181-200

44. Sigue C, Moundi A, Ndema MJL, Vishiti A, Kedia AC, Suh CE, Nzenti JP (2019) Quartz-rich fault rocks as potential high purity quartz source (I) in a sequence of the central cameroon shear zone (Etam Shear Zone): geology and structure. In: Rossetti F et al (eds) The structural geology contribution to the AfricaEurasia geology: basement and reservoir structure, ore mineralisation and tectonic modelling. https://doi.org/10.1007/9783-030-01455-1_16

45. Santos MFM, Fujiwara E, Schenkel EA, Enzweiler J, Suzuki CK (2014) Quartz resources in the Serra de Santa Helena formation, Brazil: a geochemical and technological study. J S Am Earth Sci 56:328-338

46. Müller A, Ihlen PM, Kronz A (2008) Quartz chemistry in polygeneration Sveconorwegian pegmatites, Froland, Norway. Eur J Miner 20:447-463

47. Mărgărit MN, Nicolae $H$, Simona Marchetti D, Bigi Simona, Gualtieri Alessandro F (2016) Progress in mineralogical quantitative analysis of rock samples: application to quartzites from Denali National Park, Alaska Range (USA). Powder Diffract 31:31-39

48. Nachlas WO, Whitney DL, Teyssier C, Bagley B, Mulch A (2014) Titanium concentration in quartz as a record of multiple deformation mechanisms in an extensional shear zone. Geochem Geophys Geosyst 15:1374-1397

49. Nachlas WO, Thomas JB, Hirth G (2018) TitaniQ deformed: experimental deformation of out-of equilibrium quartz porphyroclasts. J Struct Geol 116:207-222

50. Nachlas WO, Teyssier C, Whitney DL, Hirth G (2018) Diffusion geospeedometry in natural and experimental shear zones. Earth Planet Sci Lett 498:129-139

51. Götze J, Möckel R (2012) Quartz deposits, mineralogy and analytics. Springer, Berlin, p 360. ISBN 978-3-642-22161-3

52. Götze J, Plötze M, Graupner T, Hallbauer DK, Bray CL (2004) Trace element incorporation into quartz: a combined study by ICP$\mathrm{MS}$, electron spin resonance cathodoluminescence, capillary ion analysis, and gas chromatography. Geochim Cosmochim Acta 68:3741-3759

53. Fruth M, Blankenburg HJ (1992) Charaketerisierung von authigenen idiomorphen Kohle- und Salinarquartzen durch Einschlussuntersuchungen. Neues Jahrbuch Mineralogie. Abhandlungen 165:53-64 (in German)

54. Spear FS, Selverstone J (1983) Water exsolution from quartz: implications for the generation of retrograde metamorphic fluids. Geology 11:82-85

55. Tarantola A, Diamond LW, Stünitz H (2010) Modification of fluid inclusions in quartz by deviatoric stress I: experimentally induced changes in inclusion shapes and microstructures. Contrib Mineral Petrol 160:825-843

56. Tarantola A, Diamond LW, Stünitz H, Thust A, Pec M (2012) Modification of fluid inclusions in quartz by deviatoric stress III: influence of principal stresses on fluid inclusion density and orientation. Contrib Miner Petrol 164:537-550

57. Wark DA, Watson EB (2006) TitaniQ: a titanium-in-quartz geothermometer. Contrib Miner Petrol 152:743-754

58. Larsen RB, Henderson I, Ihlen PM, Jacamon F (2004) Distribution and petrogenetic behaviour of trace elements in granitic pegmatite quartz from South Norway. Contrib Miner Petrol 147:615-628

59. Breiter K, Müller A (2009) Evolution of rare-metal granitic magmas documented by quartz chemistry. Eur J Miner 21:335-346

60. Beurlen H, Müller A, Silva D, Da Silva MRR (2011) Petrogenic significance of trace-element data analyzed with LA-ICP-MS in quartz from the Borborema pegmatitic province, northeastern Brazil. Miner Mag 75:2703-2719

61. Rusk BG, Lowers H, Reed MH (2008) Trace elements in hydrothermal quartz; relationships to cathodoluminescent textures and insights into hydrothermal processes. Geology 36:547-550

62. Jourdan AL, Vennemann TW, Mullis J, Ramseyer K (2009) Oxygen isotope sector zoning in natural hydrothermal quartz. Miner Mag 73:615-632

63. Müller A, Herrington R, Armstrong R, Seltmann R, Kirwin DJ, Stenina NG, Kronz A (2010) Trace elements and cathodoluminescence of quartz in stockwork veins of Mongolian porphyrystyle deposits. Miner Depos 45:707-727

64. Monecke T, Kempe U, GÖtze J (2002) Genetic significance of the trace element content in metamorphic and hydrothermal quartz: a reconnaissance study. Earth Planet Sci Lett 202:709-724

65. Baron MA, Stalder R, Konzett J, Hauzenberger CA (2015) OHpoint defects in quartz in B-and Li-bearing systems and their application to pegmatites. Phys Chem Miner 42:53-62

66. Korneliussen A, Wanvik JE, Müller A, Ihlen PM (2006) Kystnære kvartsressurser i Hordaland. Geological Survey of Norway, Report 2006.045

67. Müller A, Ihlen PM, Wanvik J, Flem B (2007) High-purity quartz mineralisation in kyanite quartzites, Norway. Miner Depos 42:523-535 
68. Ihlen PM, Muller A, Larsen RB, and Henderson I (2007) Transformation of igneous quartz to high-purity quartz in granitic pegmatites of South Norway Granitic Pegmatites. Paper presented at the State of the Art-International Symposium, Porto, Portugal. Retrieved from http://www.fc.up.pt/peg2007/files/ihlen .pdf. Accessed July 2019

69. Weil JA (1993) A review of EPR spectroscopy in alpha-quartz: the decades of 1982-1992. In: Helms CR, Deal BE (eds) Physics and chemistry of $\mathrm{SiO}_{2}$ and the $\mathrm{Si}-\mathrm{SiO}_{2}$ interface, vol 2. Plenum Press, New York, pp 131-144

70. Weil JA (1984) A review of electron spin spectroscopy and its application to the study of paramagnetic defects in crystalline quartz. Phys Chem Miner 10:149-165

71. Anders E, Grevesse N (1989) Abundances of the elements: meteoritic and solar. Geochim Cosmochim Acta 53:197-214

72. Iwasaki H, Iwasaki F, Oliveira VAR, Hummel DCA, Pasquali MA, Guzzo PL, Watanabe N, Suziki CK (1991) Impurity content characterization of Brazilian quartz lasca. Jpn J Appl Phys 30:1489-1495

73. Götze J, Pan Y, Müller A, Kotova EL, Cerin D (2017) Trace element compositions and defect structures of high-purity quartz from the Southern Ural Region, Russia. Minerals 7:189. https://doi. org/10.3390/min7100189

74. KempeULF GötzeJ, Dombon E, MoneckeT Poutivtsev M (2012) Quartz regeneration and its use as a repository of genetic information. In: Götze J, Möckel R (eds) Quartz: deposits, mineralogy and analytics. Springer, New York. https://doi.org/10.1007/9783-642-22161-3_15

75. Stalder R, Konzett J (2012) OH defects in quartz in the system quartz-albite-water and granite-water between 5 and $25 \mathrm{kbar}$. Phys Chem Miner 39:817-827

76. Schron W, Bauman L, Rank K (1982) Zur Charakterisierung von Quartz- generationen in den postmagmatogenen Ertzformationen des Erzgebirges. Zeitschrifit für Geol Wiss 16:229-244 (in German)

77. Heynke U, Leeder O, Schulz H (1992) On distinguishing quartz of hydrothermal or metamorphogenic origin in different monomineralic veins in the eastern part of Germany. Miner Petrol 46:315-329

78. Götze J, Plötze M, Habermann D (2001) Cathodoluminescence $(\mathrm{CL})$ of quartz: origin, spectral characteristics and practical applications. Miner Petrol 71:225-250

79. Rusk B, Reed M, Dilles J, Kent A (2006) Intensity of quartz cathodoluminescence and trace element content of quartz from the porphyry copper deposit in Butte, Montana. Am Miner 91:1300-1312

80. Spear FS, Wark DA (2009) Cathodoluminescence imaging and titanium thermometry in metamorphic quartz. J Metamorph Geol 27:187-205

81. Schmatz J, Urai JL (2011) The interaction of migrating grain boundaries and fluid inclusions in naturally deformed quartz: a case study of a folded and partly recrystallized quartz vein from the Hunsrück Slate. Ger J Struct Geol 33:468-480

82. Romer RL, Franz L, Wirth R (2006) Chemical and isotopic effects of retrogression in metamorphic fluid inclusions. Contrib Mineral Petrol 151(2):174-186

83. Schmidt C, Bruhn D, Wirth R (2003) Experimental evidence of transformation plasticity in silicates: minimum of creep strength in quartz. Earth Planet Sci Lett 205:273-280

84. Vityk MO, Bodnar RJ, Doukhan JC (2000) Synthetic fluid inclusions. XV. TEM investigation of plastic flow associated with reequilibration of fluid inclusions in natural quartz. Contrib Miner Petrol 139:285-297

85. Roedder E (1984) Fluid inclusions. Reviews in mineralogy, vol 12. Mineralogical Society of America, Washington

86. Diamond LW, Tarantola A, Stünitz H (2010) Modification of fluid inclusions in quartz by deviatronic stress. II: experimentally induced changes in volume and composition. Contrib Miner Petrol 160:845-864

Publisher's Note Springer Nature remains neutral with regard to jurisdictional claims in published maps and institutional affiliations. 